\title{
KUTATÁS
}

\author{
KASZAP-ASZTALOS EMESE
}

\section{A MAGYAR POLITIKAI-KULTURÁLIS KARIKATÚRA ISMERETLEN KEZDETE: PETRICHEVICH HORVÁTH JÁNOS RAJZMAPPÁI}

Kolozsváron a Román Tudományos Akadémia Könyvtárában található négy rajzmappa, ${ }^{1}$ mely több száz, 1824-1864 között készült képet, karikatúrát, zsánerképet, miliőrajzot, politikai portrét stb. tartalmaz Petrichevich Horváth Jánostól. Az albumok számos alig ismert, még sosem publikált ábrázolást foglalnak magukba a korszak szereplőiről, Széchenyi Istvánról, Wesselényi Miklósról, Teleki Lászlóról, Teleki Sándorról, V. Ferdinándról, Metternichről vagy Ferenc Józsefről, valamint a kor kevésbé illusztris alakjairól, így az erdélyi közélet, nemesség tagjairól vagy a császári katonaság tisztjeiről. A több mint félezer (olykor csak vázlatosan kidolgozott) rajz nemcsak ikonográfiai szempontból jelentős, hanem művészi értéket is képvisel. A gyüjteményben - ha nem is hivatásos, de - tudatos, képzett alkotó munkái láthatók, melyben kifinomult rajztechnika, színkezelés, gondos térbeli kompozíciók és anatómiai ábrázolások, helyes perspektivikus látásmód, érzékeny karakterábrázolás és jellemzőerő figyelhető meg, a rajzok pedig a kor egyes művészi/tematikus tendenciáit is bemutatják.

Ami az albumok grafikáinak ismertségét illeti, a rendkívül értékes (forrás)anyag egy-egy darabja mindeddig elvétve jelent csak meg a történeti irodalomban. A rajzmappákról sem repertórium jellegü ismertetést nem tettek közzé, sem reflexív-elemző képet nem adtak. Legkorábbi, eddig felderített említése 1944-re datálható, mikor Bíró Béla művészettörténész az erdélyi biedermeier kutatásának során Bánffy Miklós könyvtárában ráakadt Petrichevich Horváth János munkáira, ennek nyomán pedig a rajzolót a ,jellegzetesen erdélyi” biedermeier stílusirányzat úttörői közé sorolta. ${ }^{2}$ Bíró érzékelte a „,testes albumok" jelentőségét, a "gondolatban és technikában egyaránt szellemes karikatúrák" fontosságát, a mükedvelő gróf tehetségét, „kinek müvészi felkészültsége messze meghaladta a dilettantizmus szokványos fokát". ${ }^{3}$ A bonchidai kastély tragikus leégése, az albumok hányódása különböző gyűjteményekben, valamint Bíró Béla disszidálása azonban megakadályozta, hogy a forrásanyag helyet kapjon a müvészettörténeti recepcióban.

Magyarországon az eredeti rajzokból - jóval később - először Rózsa György publikált tizenegyet 1973-ban Spira Györggyel közösen összeállított kötetükben, a Negyvennyolc a kortársak szemével címü nagyszabású - a képeket és szövegeket azonos értékü forrásként kezelő - gyüjteményben. ${ }^{4}$ E forrásanyag jelentőségére külön egyikük sem tért ki. A történész érdeklődését Petrichevich Horváth János nem is foglalkoztathatta hosszasabban, miután a szabadidejében rajzoló, műkedvelő báró (majd gróf) ${ }^{5}$ a „,meg nem semmisített reakció képviselője” ${ }^{\prime 6}$ volt, aki a császári haderők ezredeseként, majd vezérőrnagyaként „,az ellenforradalom szervezése” és a szabadságharc leverése érdekében harcolt. Spira később még egy rövid ismeretterjesztő cikkben írt a rajzmappa egyik tematikai szempontból különösen izgalmas képéről, amely Széchenyi Istvánt ábrázolja a Dunában úszva, háta mögött a hajóhíddal, a rakparton szemlélődő emberekkel. ${ }^{7}$ Spira rögzítette a rajz tárgyi jelentőségét, miután nem ismert másik ábrázolás az 1830-as évekből Széchenyi Lánchíddal kapcsolatos küzdelmeiről (ti. amint az árral szembe úszik). Spira röviden elintézte az 1836-ban készült kép mondanivalóját, kijelentve, hogy megfellebbezhetetlenül és beszédesen arról vall, hogy Széchenyi sokáig nem tudott sikerre jutni a Lánchíd ügyében, az aulikus beállítódású Petrichevich Horváth Jánost pedig „diadalérzet és káröröm töltötte $\mathrm{el}^{\prime 8}$ ennek kudarcát látva. Spira nem foglalkozott a rajz egyéb 


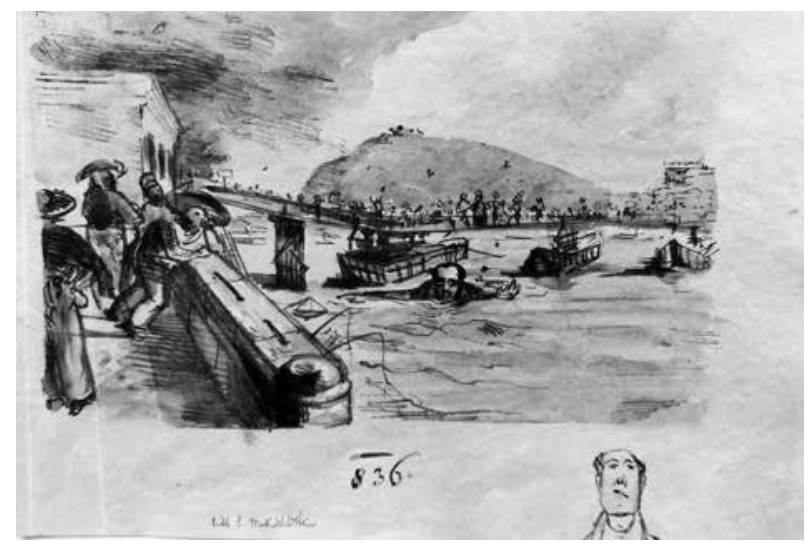

1. Petrichevich Horváth János:

Széchenyi István úszik a Dunában, 1836

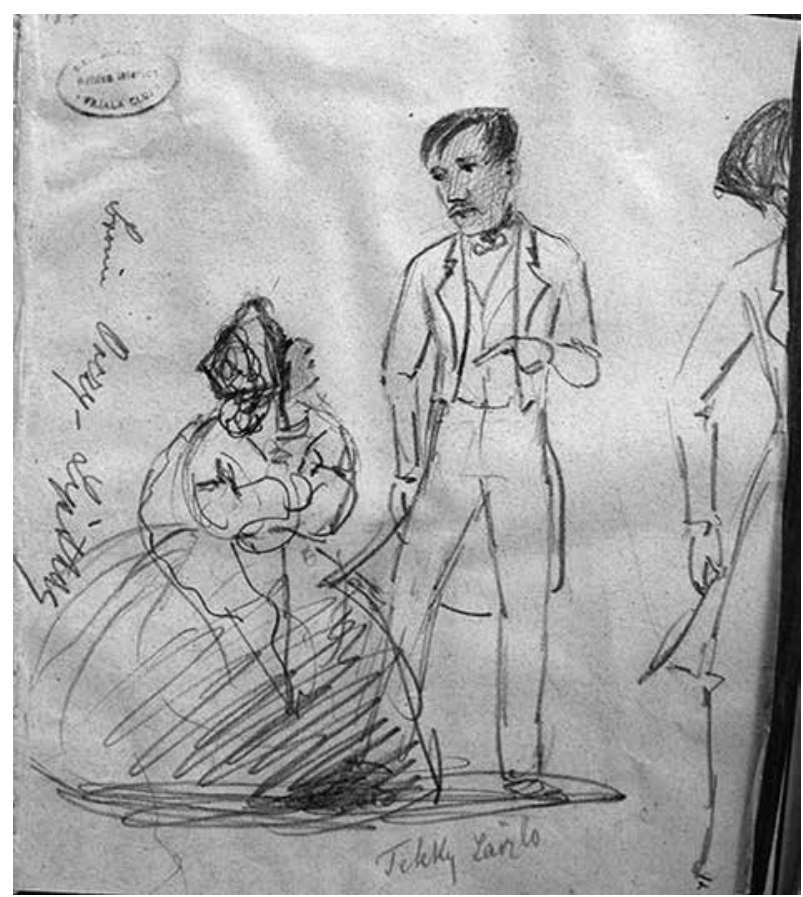

2. Petrichevich Horváth János: Teleki László és Orczy Istvánné Lipthay Auguszta bárónó, 1841

értelmezhetőségi lehetőségével és az effajta pszichologizáló magyarázat bizonytalanságaival sem. A továbbiakban a (számára) rendkívül ellenszenves rajzoló (aki például erős jelzőhasználatában „a legsötétebbek sorába tartozó Jósika Samu" sógora volt) kikerült a tudós látószögéből.

Az albumok e jó néhány évtizeddel ezelőtti feltünésük után nemrég újra felbukkantak. 2010-ben épp az említett Széchenyi-akvarell szerepelt a Széchenyi világai című tárlaton a Nemzeti Múzeumban, majd 2011-ben a Teleki László-emlékkiállításon a „közismert ábrázolások mellett - másolatban - két különleges képen is feltün[t] Teleki alakja". ${ }^{9}$ Ezek a politikus legkorábbról ismert portréi. Petrichevich Telekiről készült rajzai közül kettő szerepelt a tár- laton: egy álló alakos kompozíció, amely „egyetlen képi emléke Teleki László és Orczy Istvánné báró Lipthay Auguszta élethosszig tartó szerelmének", valamint egy 1841-es csoportkép, amelyen az erdélyi országgyưlés diskuráló alakjai közt látható a politikus. A cikk először közölt a rajzmappák egészére vonatkozó értékelést: „Petrichevich albumainak és rajzainak kiemelt fontosságát az adja, hogy a korszakból alig áll rendelkezésünkre a reprezentatív ábrázolásokon kívüli képi források ilyen gazdag, több száz darabos gyüjteménye." ${ }^{10}$ További vizsgálódásokat azonban nem folytattak, így az albumok szélesebb összefüggésbe helyezésére, a képek müfaji, valamint ikonográfiai megközelítésére és a mappák müjegyzék-jellegü áttekintésére ebben a tanulmányban nyílik először lehetőség. A részletesebb vizsgálatok előtt azonban érdemes Petrichevich Horváth János pályájával és kapcsolati hálójával röviden megismerkedni, legalábbis amennyire ezt a rendelkezésre álló források lehetővé teszik. ${ }^{11}$

Erdélyben a Petrichevich Horváth a mai napig ismerősen csengő családnév, egyfelől az erdélyi fejedelemség udvarában, ${ }^{12}$ másfelől az unitárius egyházban betöltött szolgálataiknak köszönhető́en. ${ }^{13} \mathrm{~A}$ Mária Terézia uralkodása alatti térítések következtében a família egyik ága, éppen Petrichevich Horváth János nagyapja, I. Dániel katolizált. A család e tagjainak elköteleződése a Habsburgok iránt ezzel vette kezdetét.

A rajzoló Petrichevich Horváth János apja, Dániel vallási és politikai lojalitása mellett a múvészetek terén vívott ki magának ismertséget. Alkotó ambíciókkal rendelkező földesúr volt, a kolozsvári kulturális élet meghatározó figurája, korának fontos művelődésszervezője. Ennek köszönhető, hogy mint színházi emberről, műkedvelő íróról (eredeti drámák és novellák szerzője, közkedvelt fordító), főúri szalonszervezőről máig megemlékezik a vonatkozó szakirodalom. „1811 óta színházszervező és mecénás, 1813/14-ben a kolozsvári társulat igazgatója. 1814-ben főúri műkedvelő együttes szervezője, ők nyitották meg a kolozsvári magyar színházat 1821-ben. 1828-ig az igazgatóválasztmány, illetve a működtető részvénytársaság elnöke. Egy eredeti drámát írt (Zuelma), s hét fordításáról tudunk" - ezeket a színmúfordításokat szívesen forgatták a kor vándorszínészei is. ${ }^{14}$ Dániel gyermekei a kor megszokott úri neveltetése, valamint apjuk artisztikus fogékonysága következtében maguk is művészetszerető és -gyakorló emberek voltak. A műkedvelő mecénás pozíciójából azonban csak a legkisebb fiú, Petrichevich Horváth Lázár igyekezett kilépni, aki rövid hivatalnoki pályafutás után szépírói, valamint lapszerkesztői hivatást választott magának. 


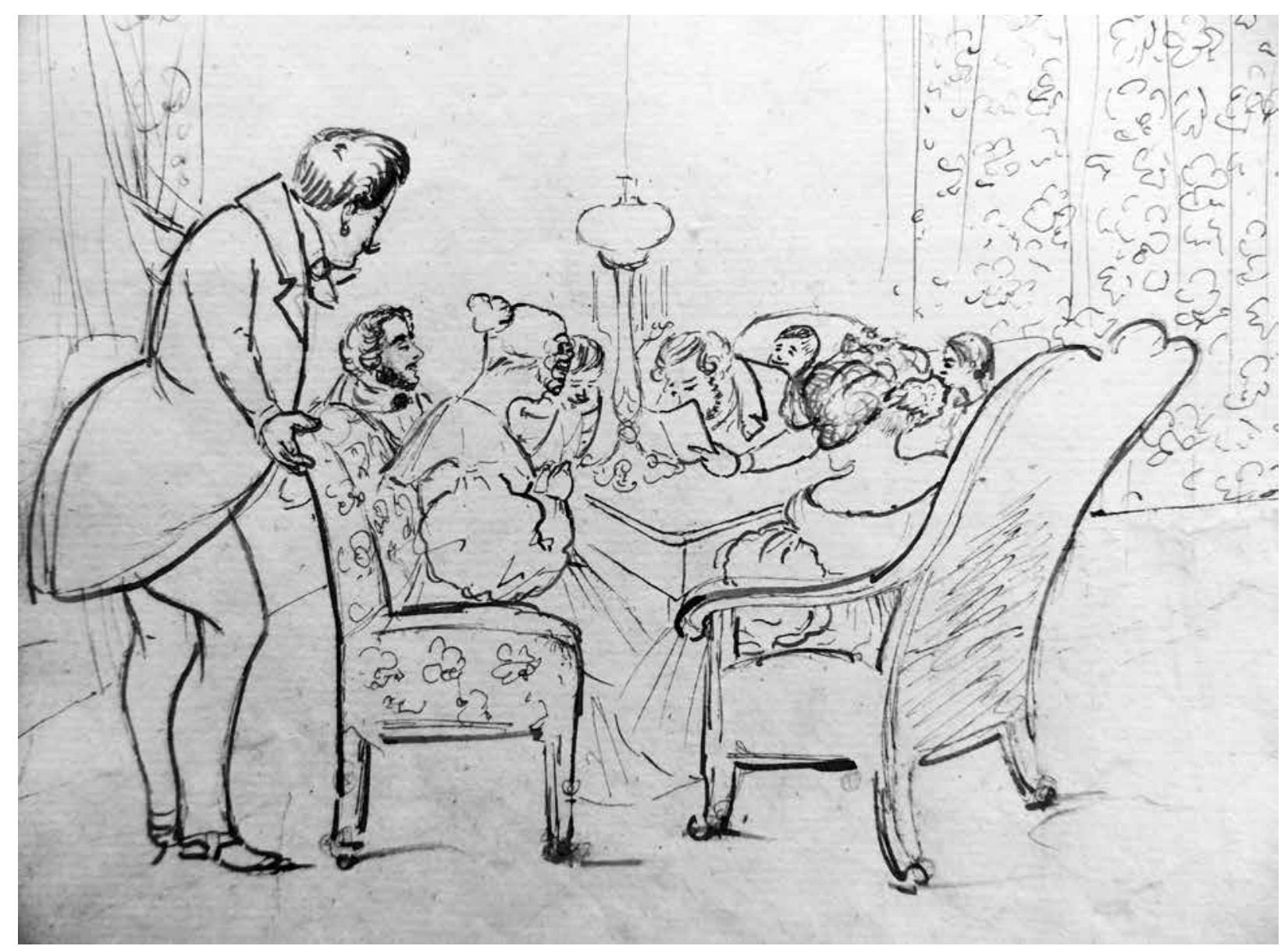

3. Petrichevich Horváth János: Széchenyi István társaságban, é. $n$.

Petrichevich Horváth János (1801-1865) rajzi képzettségére vonatkozóan csupán családi vagy lakóhelyének körülményeiből lehet következtetni. Gyaníthatóan gyermekkorától kezdve rangjának megfelelő nevelésben, így viszonylag rendszeres rajzoktatásban is részesülhetett. Erre a rajzok kvalitásán kívül a gyermekek jól dokumentálható, más területekre kiterjedő, múvészi igényű taníttatása utalhat. A család francia nevelője zenei előmenetelükről gondoskodott, ${ }^{15}$ emellett „klavírozni” Schodel János (a később híres magyar operaénekesnő, Schodelné Klein Rozália férje) tanította őket. Apjuk színházi működése folytán a gyerekek családi körben maguk is játszottak, rendeztek színi előadásokat. ${ }^{16} \mathrm{Az}$ írás mindennapos és alapvető kifejezési forma volt otthonukban, ${ }^{17}$ szalonjaikban pedig meg-megfordult Barabás Miklós (1810-1898) is: ${ }^{18}$ a festő 1836-ban Horváth Lázárról, 1839-ben „Horváth János kapitányról" arcképet is készített. ${ }^{19} \mathrm{~A}$ famíliában folyó képzőművészeti képzésről tanúskodhatnak továbbá János öccse, Lázár művészeti írásai, fogékonysága a festészet iránt, későbbiekben pedig szerepvállalása a magyar képzőmúvészet önállósulási folyamatában. ${ }^{20}$
Petrichevich Horváth János - a korszak más aulikus nemesi család sarjaihoz hasonlóan, legfőképp pedig elsőszülött fiúként - felsőfokú tanulmányait Bécsben folytatta az Ingenieur Academián, és ennek elvégzése után egyre feljebb lépkedett a katonai ranglétrán. Kezdetben különböző huszárezredekben szolgált, rövid ideig parancsnoki rangban volt a bécsi magyar nemes testőrségnél is (egészen annak 1849-es feloszlatásáig), az 1850-es és 60-as években pedig császári hadtesteknél magas rangú katona. ${ }^{21}$ Az udvar légkörében nevelkedett, ${ }^{22}$ és talán éppen a korszakban terjesztett össznemzeti gondolatrendszer, a "birodalmi patriotizmus" következtében "tántoríthatatlan és valóban hazafias érzet tölti el a törzsökös császári ház irányába", ${ }^{23}$ így a rendiség és a monarchia elkötelezett védelmezőjeként az osztrák csapatok élén először ezredesként, végül vezérőrnagyként küzdött a magyar szabadságharc leverésért. Identitása mindemellett nem homogén, és bár az 1830-as évek második felétől (elsősorban 1836-ban elhunyt neje, Jósika Jozefa halálának következtében) Erdéllyel egyre inkább megszakadt a kapcsolata, magyar születése mindvégig meghatározó maradt számára. Ennek sajátos megnyilvánu- 


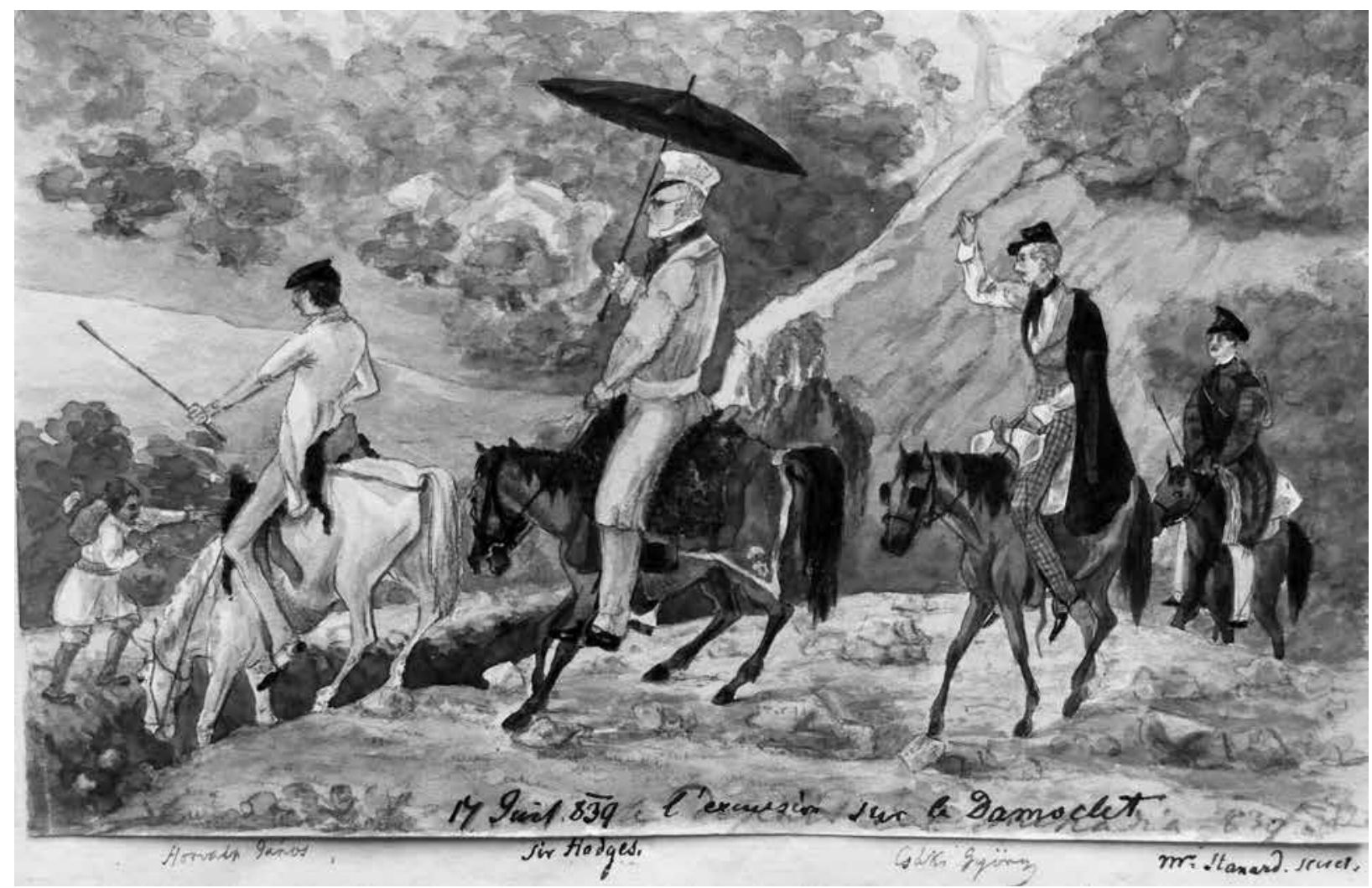

4. Petrichevich Horváth János: Sir Hodges, Csáky György és Petrichevich Horváth János kiránduláson, 1839

lása, hogy például 1848 márciusának bécsi eseményeiről szóló rövid memoárját magyar nyelven írta. Konzervatív, lojális értékrendjébe a szabadságharc leverését követő önkényuralom már nem volt beilleszthető. A reformkori közbeszédben az aulikus, konzervatív elnevezés gyakran alkotmányellenes, abszolutisztikus irányú szitokszóként szerepelt, ezt azonban árnyalja, hogy „az 1850-es években, amikor Ferenc József császár rendelettel szüntette meg a magyar alkotmányosságot, s Magyarországot beolvasztotta az egységes birodalom központosított igazgatási rendszerébe, a konzervatívok többsége nem vállalt politikai szerepet, csoportjuk az abszolutista kormányzat ellenzékének számított". ${ }^{24}$ Petrichevich visszaemlékezéseiben kitért például arra, hogy 1852-ben Felix zu Schwarzenbergnél panaszt tett az abszolutista, jogsértő eljárások miatt: „amint egyet-mást kérdett tőlem Erdélyről, az ott lévő idegen hivatalnokok zsarolását és erőszakoskodását említettem, kiknek minden céljok csak a zseb megtöltésére volt irányozva" ${ }^{25}$ Lelki sorsközösséget vállalt továbbá benső barátjával, Jósika Sámuellel, a korábbi erdélyi kancellárral is, akinek az ötvenes években végigasszisztálta meghasonlását a hatalommal: „Schwarzenberg herceg és Jósika Samu egymással sokáig a legnagyobb barátságban éltek. [...] S mégis nemsokára köztük egy oly nyílás támadt, mely őket örökre elválasztá egymástól az életben." Az olmützi oktrojált alkotmány ugyanis „,keserűn sértette a magyar urakat, kik hazájuk ezen szomorú sorsában csak a birodalom szomorú jövendőjét látták. [...] Az évről-évre növekedő elkeseredése a magyar honfiaknak B. Jósika Samuban volt tökéletesen képviselve, ki Schwarzenberg iránti gyưlöletét nyilvánosan is kimutatta. Báró Jósika Bécsben lakott. Az ő szállása gyưlőhelye [sic!] volt a kormányformával elégedetlen honfiaknak. [...] Amidőn ezen társaságban szó került a haza jövendőjéről, B. Jósika Samu nagyon magába merült [...]. Gyakran felkereste Gr. Széchenyi István barátját. [...] Április 7-én, tíz nappal B. Jósika halála után Gr. Széchenyi is Döblingben pisztolylövéssel kivégezte magát." ${ }^{26}$

Petrichevich Horváth János tetteinek motivációi, világképének változásai a maguk „valóságában" természetesen rekonstruálhatatlanok, és - amint Spira olvasata kapcsán is láthatóvá vált nagyban függnek az adott értelmezői kor prioritásaitól. Végérvényes magyarázat rögzítésének lehetetlenségéhez pedig már csak adalék az a filológiai tény, hogy Petrichevich esetében feltünően kevés primer forrásra vagy akár szekunder irodalomra lehet támaszkodni. Petrichevich Horváth János rajzai nyomán összetettebb, ellentmon- 


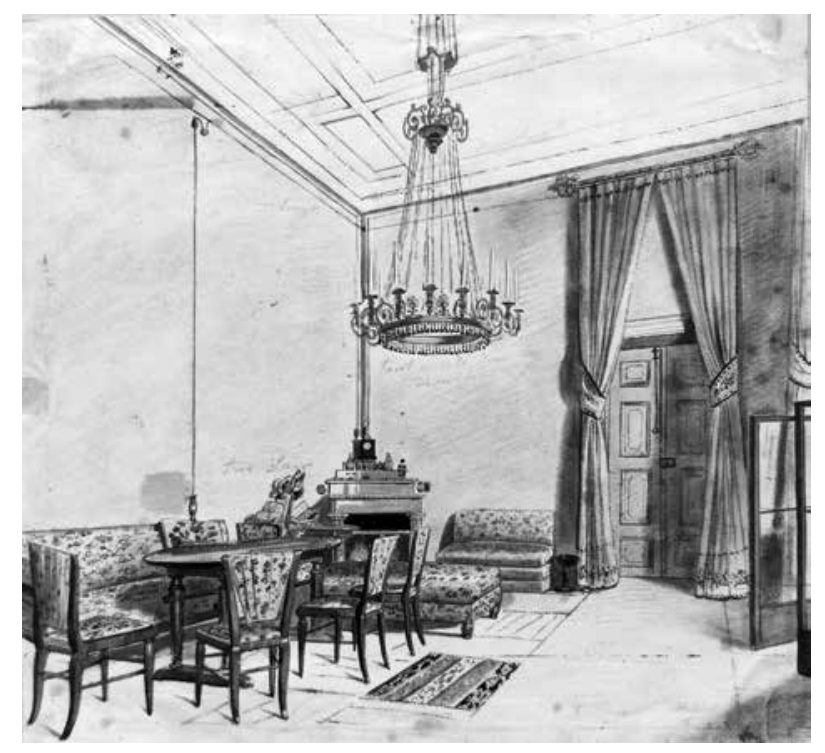

5. Petrichevich Horváth János: Szobabelső olvasó hölggyel, é. $n$.

dásosabb kép rajzolódik ki „reakciós” életútjával kapcsolatban. A „Magyarországra törő WindischGrätz egyik legbuzgóbb alparancsnoka", vagyis az engedelmes katona és funkcionárius mellett egy vizuálisan érzékeny, élményeire képileg reflektáló, tehetséges műkedvelő is feltűnik, és a mappákban található számos "torzkép” müfaja mentén különösen is sokoldalúbbnak mutatkozik alakja. A karikatúra ugyanis éppen a lényeglátást, az ellentmondások kifejezését teszi lehetővé, Greguss Ágost (aki a "torzkép" müfajáról először adott magyar nyelven teoretikus áttekintést) érzékletes paradoxonjaival szólva: „kicsinyes nagyság, gyönge ero”, baromi magasztosság, fenséges semmiség, otromba kellem, csinos durvaság, értelmes értelmetlenség, üres teljesség" ${ }^{27}$ egyszerre mutatkozhat meg benne. A „torzkép” eredendően a világ hierarchikus rendjének megkérdőjelezésére irányul, amely komikus vonásai következtében azonnal egyfajta frusztrációt tompító gesztussá válik, hiszen „humorában felolvad minden fájdalom, melyet a gyarlóság és tökéletlenség érzete lelkünkben szüll" ${ }^{28} \mathrm{Ez}$ a sajátos „túlélési mechanizmus" az illusztrálás során távolságot teremthet, a tárgyiasítás során pedig átértékelheti viszonyát az ábrázolttal, és képes kilátástalan helyzetét nevetésbe transzponálni.

Amellett tehát, hogy a képek önismereti, létértelmező paradigmába (is) illeszthetők, amelyek a tapasztalatok, sztereotípiák produktív átrendezésére, átértékelésére adnak lehetőséget, müfajtörténeti jelentőséggel is bírnak. Petrichevich Horváth János a magyar a politikai, kulturális karikatúra eddig kevéssé ismert kezdeteinek egyik kulcsfigurájaként határozható meg, torzképei új perspektívába állíthatják az ábrázolásmód hazai indulását. ${ }^{29}$

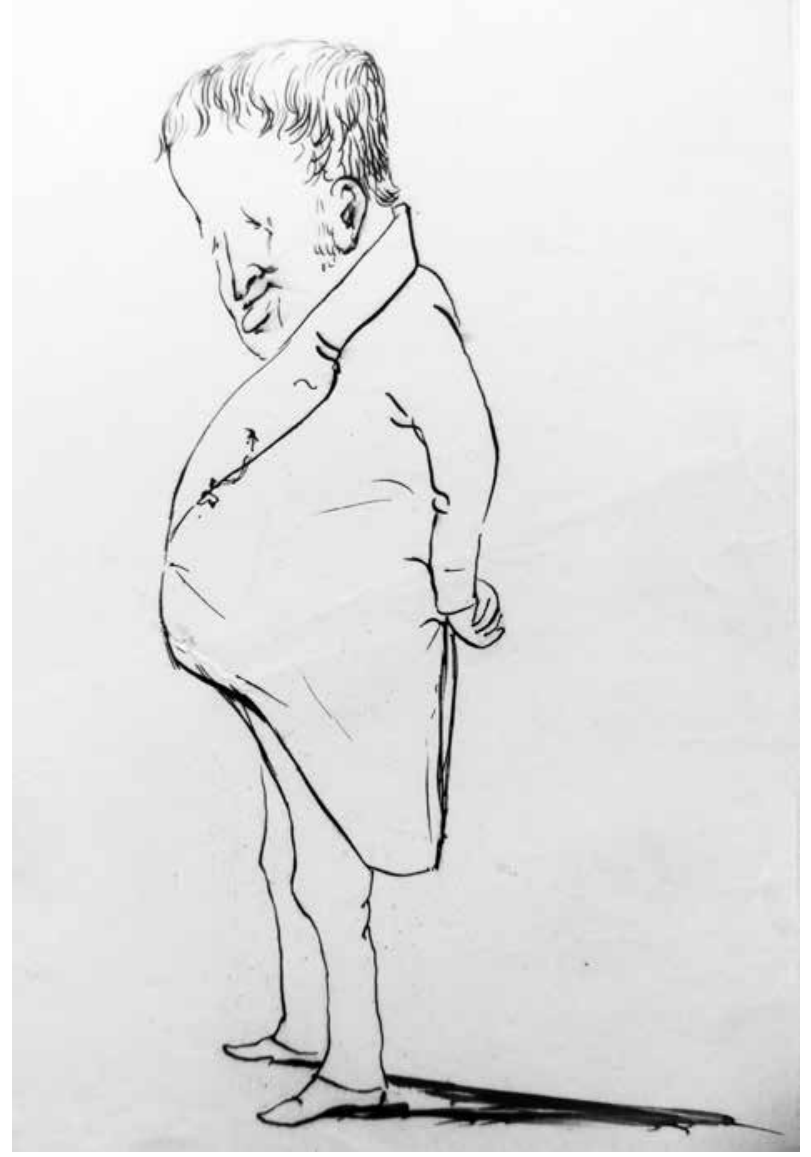

6. Petrichevich Horváth János: V. Ferdinánd, é. $n$.

Az albumok egy olyan átmeneti korban születtek, amelyben a fóúri dilettáns rajzkultúra, valamint az épp intézményesülő magyar képzőművészet egyszerre hatott. A század első felének professzionális törekvései (Pesti Múegylet, Marastoni Rajziskola) mellett így nagyobb hangsúlyt kaphattak a dilettáns képzőművészeti megnyilvánulások is. A rajzolás ráadásul a biedermeier élet/stílus sajátosságaként a nemesi (és polgári) körökben gyakori tevékenységnek számított. „Azokban a családokban, ahol gondot fordítottak a nevelésre, gyermekeik mellé rajztanárt, zongoramestert és francia nyelvmestert fogadtak." A Madách-házban például Majthényi Anna akvarelljei függtek a falon, Madách Imre rajzai, karikatúrái és olajfestményei pedig fontos elemét képezték a költő „'magánjelrendszerének”. ${ }^{30}$ Jókai „romantikus" életmüvének érdekes pandanja a pályája elejéről származó néhány festmény. Ezek - a sztregovai remete "gyenge alkotásaival" szemben némi múvészi alkotóerőről is árulkodnak, s az 1850es években készült erdélyi tájrajzai, illetve egyes karikatúrái megjelentek újság vagy könyv illusztrációjaként. ${ }^{31} \mathrm{~A}$ korszak főként múkedvelő munkái közül legtöbb történeti, ikonográfiai jelentőségü, 


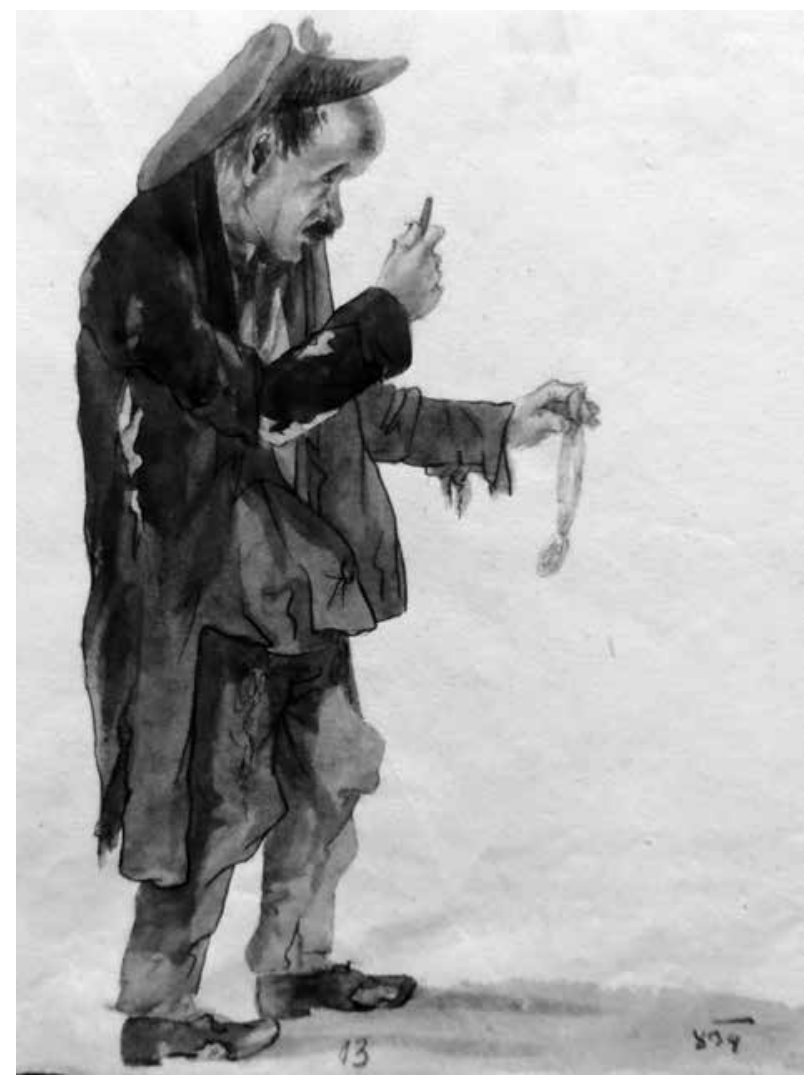

7. Petrichevich Horváth János: Bolond Samu Kolozsvárt, 1834

így például Széchenyi Franciskáé, „aki egész albumot festett tele a család életének kisebb-nagyobb eseményeivel". ${ }^{32}$ Külön művelődéstörténeti, olykor esztétikai súllyal rendelkeznek a század első feléből való utazóalbumok, Forray Iván Utazási albuma vagy Andrássy Manó Utazás Kelet Indiákon, illetve Hazai vadászatok és sport alkotásai. Gróf Andrássy Emánuel (Manó) egyébként a karikatúra müfajában is jeleskedett. 1841-ben a Múkiállításon a Pesti utcaseprő gyermek címú rajzával szerepelt, az 1847-48-as országgyülésen pedig „,nem kiváló szónoklatokkal, hanem szellemes rajzokkal tünt $\mathrm{ki}^{\prime \prime}$, amelyeket a népszerű képviselőkről készített, valamint alkotott egy tíz képből álló karikatúra-sorozatot is, amelyben a „forradalom nehézségei elől húzódó forradalmárokat" mutatta be. ${ }^{33}$

Petrichevich alkotásainak egy része ceruzával, nagyobb része vízfestékkel készült, ez utóbbi technika „a 19. század elejétől a széles körü polgárosodással lett hallatlanul népszerú Európa-szerte, [...] az albumokat megtöltő akvarell-arcképek, tájképek vagy apró zsánerek a francia rokokó szellemi légkörében terjedtek el, ennek játékossága, intim méretekhez vonzódása, kifejezéskészlete" került át biedermeier eszköztárába. ${ }^{34}$ Petrichevich albumai tehát a biedermeier rajzkultúra népszerű képtípusainak (portré, miliőrajz, zsánerkép, elvétve tájkép) rangos gyűjteményei. Az akvarell illanó hatású, áttetsző színei közvetlen, könnyed, intim hangulatot kölcsönöznek a kisméretü festményeknek, maga a technika (pl. a gyorsabb száradás miatt lendületesebb festés) pedig spontaneitást igényel, ami a karikatúrák természetével is összhangban áll. Az akvarell korrekt használata ráadásul gyakorlott müvészre vall, hiszen a hibák kevéssé javíthatók, és a színek kikeverése is nagyobb tapasztalatot igényel. E nehézségek ellenére a technika további előnye, hogy a vízfestéket, rajzónt könnyen magával vihette a müvész akár a szalonba, a bálterembe, politikai gyülésekre vagy csatatérre: „e felszereléssel nekiindulva [...] a jelenségek illékonyságát, a helyzetek hangulatát igen gyorsan a helyszínen" lehetett rögzíteni. ${ }^{35}$

A karikatúra ${ }^{36}$ alapvetô feltétele az urbanizáció, a polgári társadalom kialakulása. Angliában a 18. század elején William Hogarth múvészetével jelent meg, majd a század második felétől James Gillray munkásságával teljesedett $\mathrm{ki}^{37} \mathrm{~A}$ mediális váltást eredményező fogyasztói és technikai változások ambivalens helyzetet idéztek elő: a karikatúra a maradandó esztétikai alkotás és egyszer használatos produktum határára került, befogadás-történetük a mai napig a politikatörténet, a sajtótörténet és a művészettörténet mezsgyéjén mozog. Míg Hogarth festményei a magas múvészet fellegvárában foglaltak helyet, Gillray kirakatba függesztett képei egyszerre tartoztak az utca népe és a müértők érdeklődési körébe. A torzképek maradandó értékét jelölheti azonban, hogy bár aktuálpolitikai vagy korspecifikus tartalmuk el is évül, ábrázolásmódjuk a mai napig elevenen hat, így akár tárgyi ismeretek nélkül is betöltheti nevettetố funkcióját. Gillray formanyelve például a müfaj olyan általános fogásait találta fel, olyan univerzális igazságokat feszeget, hogy hatása napjainkig érezhető ${ }^{38}$ Máig érvényes értéküket biztosítja továbbá, hogy a korszak teljesebb körü ismeretéhez segíthetnek hozzá. Bahtyin karneválelméletéből kiindulva: a karikatúra a „hivatalos" társadalmi rend mellett létező, a nevetés természetére alapozó mindenkori szubkultúrát, a hatalom visszásságait, „,valós” természetét tárhatja fel.

A kontinensen a francia forradalom alatt keletkeztek az első modern értelemben vett karikatúrák, majd a polgárkirály, Lajos Fülöp uralkodásának kezdetével egy időben, 1830-ban az első élclap, a $L a$ Caricature is megszületik Párizsban. A század első felében - főként francia minták nyomán - Európa minden jelentősebb nagyvárosában (nyomdatechnikai fejlettségük függvényében) létrejöttek a napi, heti vagy havi megjelenésü élclapok.

A vonatkozó összefoglalások a magyar karikatúra tanulmányozását az 1860-as évekkel kezdik, ahol az 1858-as Üstökös, valamint az 1860-as Bolond Mis- 


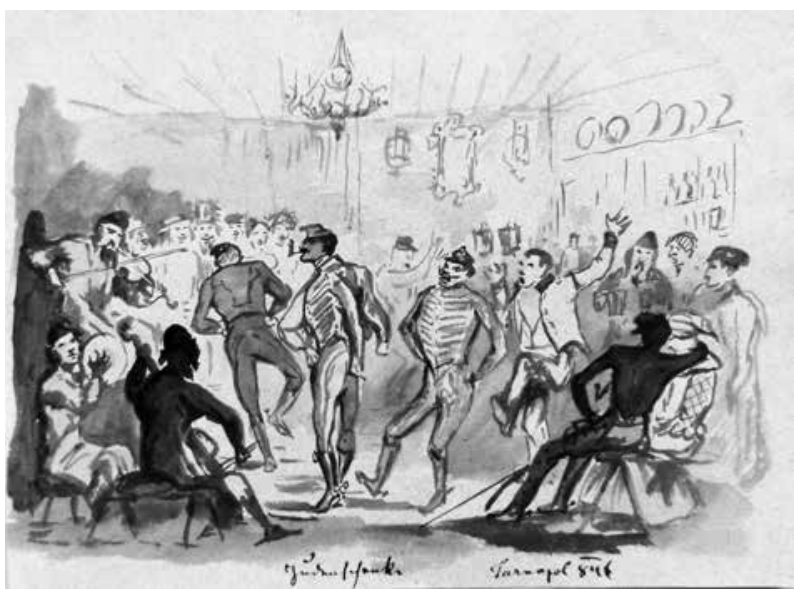

8. Petrichevich Horváth János: Mulató katonák, Tarnopol 1846

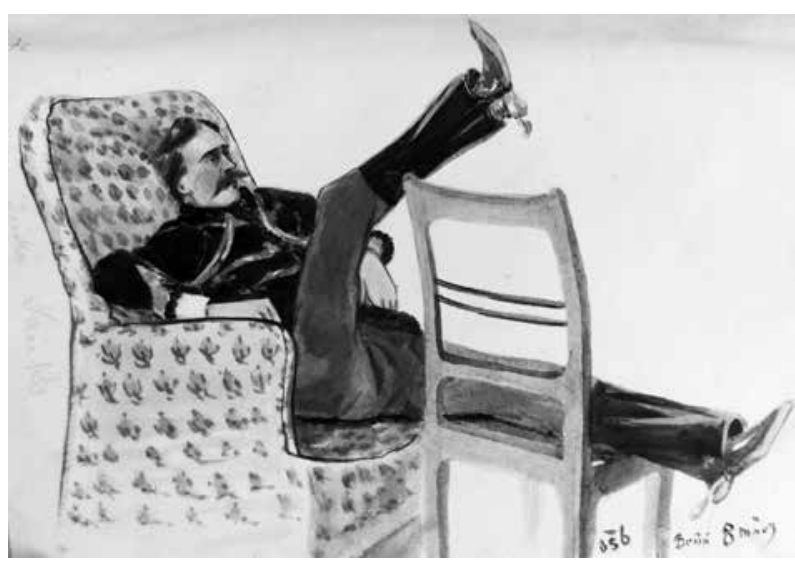

9. Petrichevich Horváth János: Pihenő tiszt, Brünn 1853

ka megjelenésétôl számítják a műfaj indulását Magyarországon, de a cenzúra fokozatos gyengülése következtében csak az 1868-ban alapított Borsszem Jankóval jön létre a korszerü, európai értelemben vett élclap itthon. Greguss 1865-ben írt cikkében ezért nyilatkozhat még így: „nálunk [...] a torzkép múvészet még majmoló gyermekkorát éli”, a magyar karikatúrák „még kevésbé eredetiek, s leginkább azokat utánozzák, melyek többnyire maguk is utánzatok, a németeket" ${ }^{39}$ A 19. század első felét ezért főképp csak kezdetleges próbálkozások idejének tekintik, melynek rövid életú betetőzését (nem véletlenül) épp a magyar függetlenségi törekvések idején megvalósuló, 1848 júliusától szeptemberig fennálló Charivari Dongó jelenti.

Petrichevich rajzainak ismeretében a müfaj korai történetét differenciáltabban láthatjuk. 1848-at megelőzően ugyanis csak elszórtan - könyvek, folyóiratok alkalmi illusztrációiként - jelentek meg humoros képek, még ha az 1840-es évek divatlap-kultúrájában már előfordultak rendszeresebb karikaturisztikus rovatok is. A számos (ön)definiá-

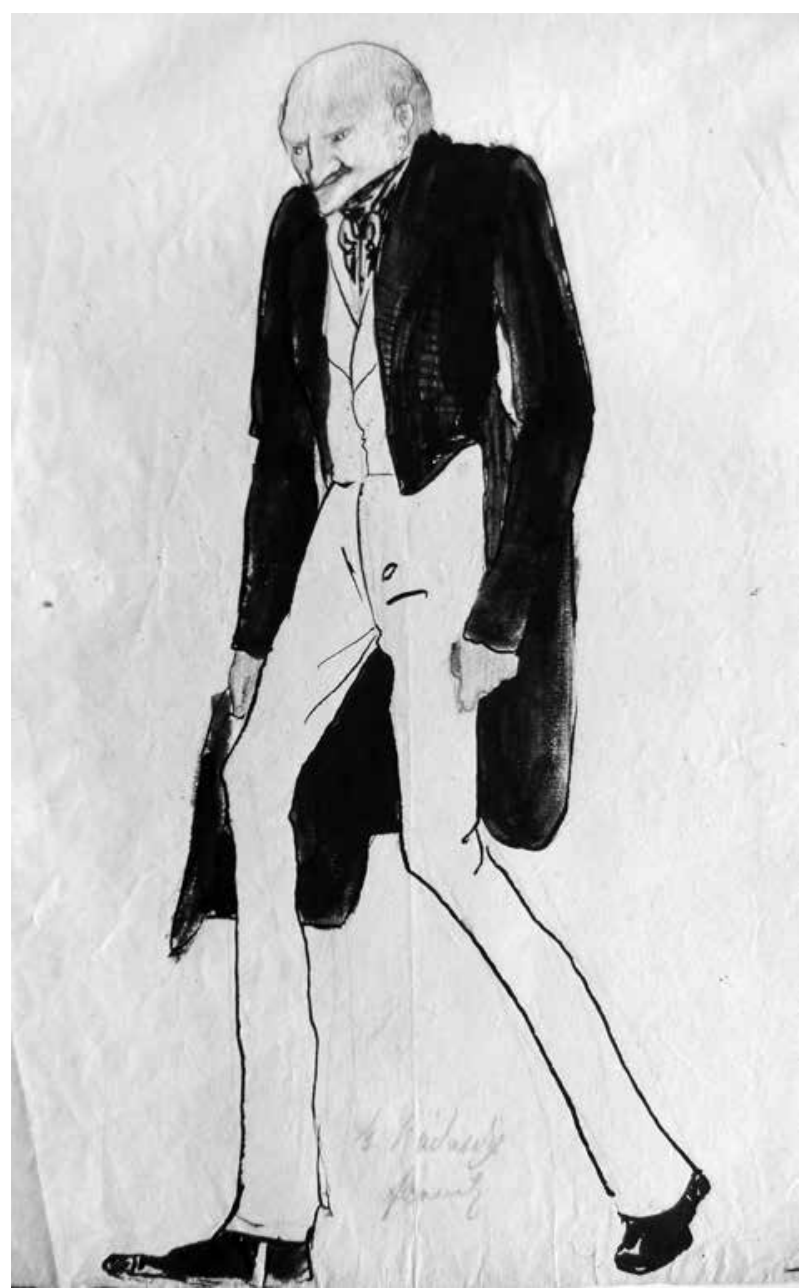

10. Petrichevich Horváth János: Nádasdy Ferenc gróf, é. n.

lási problémával, intézményesülési nehézséggel, infrastruktúra hiányával stb. bajlódó reformkori magyar „képzőművészet” természetesen nem rendelkezett olyan jelentős karikaturista-müvésszel, mint például az említett James Gillray (1756-1815) vagy akár a francia Honoré Daumier (1808-1879). Petrichevich Horváth János rajzmappáinak feltárásával azonban összemérhetővé válnak a műfaj európai és hazai megnyilvánulásai. Míg Gillray számára múvei megélhetést jelentettek, hisz a képek után kapott kormányzati járulékból tartotta fent magát, ahogyan Daumier is hivatásos karikaturistaként, sajtónyilvánosság számára készítette múvészi igény(esség)ü torzképeit, addig Petrichevich gyaníthatóan műkedvelőként, privát albumai részére rajzolt (legalábbis az eddig feltárt levéltári források erre engednek következtetni) ${ }^{40}$ müveik azonban több ponton - már csak a múfaj struktúrájából következően is - rendelkeznek hasonlóságokkal. Ennek érdekes megnyilvánulása például, hogy Gillray legtöbb karikatúrája a porfíriából eredő mentális beteg III. Györgyöt állítja pellengérre, 


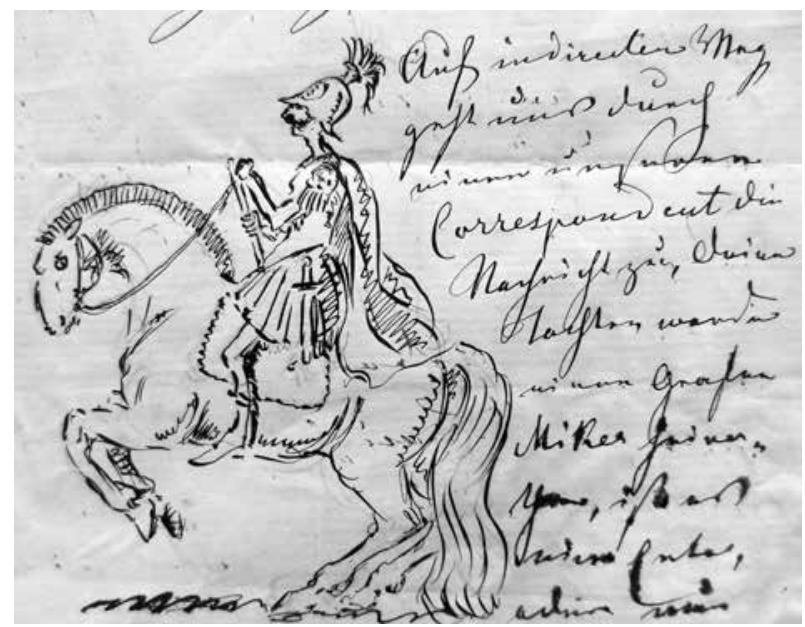

11. Petrichevich Horváth János önkarikatúrája egy levélben

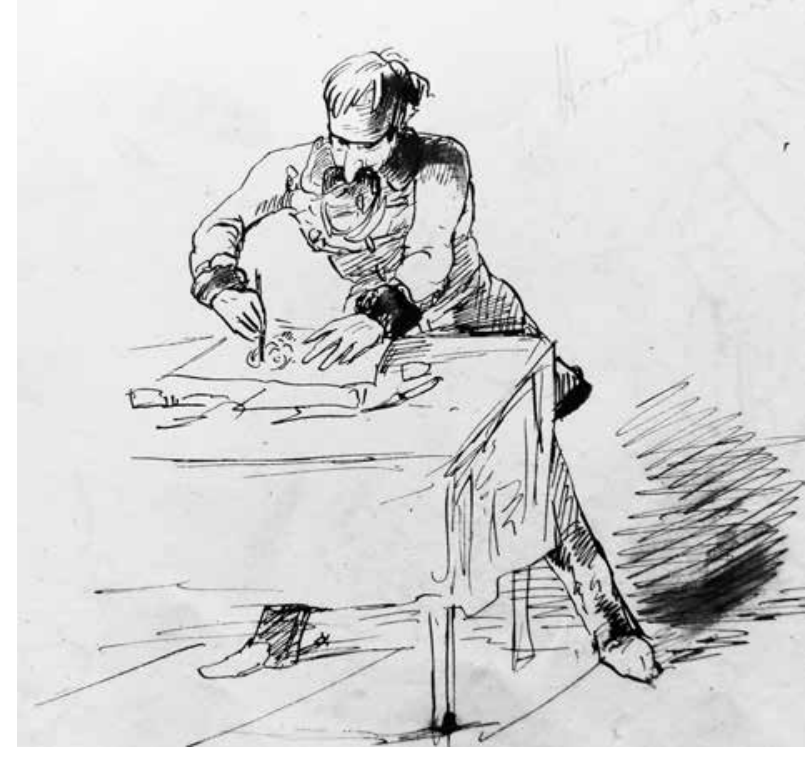

12. Petrichevich Horváth János önarcképe, é. $n$.

amint Daumier leghíresebb torzképe is a körtefejü polgárkirályt, Lajos Fülöpöt ábrázolja, Petrichevich pedig ugyancsak több skicc-karikatúrát készített a vízfejü V. Ferdinándról, akinek társaságában rendszeresen tartózkodott, és visszaemlékezéseiben írásos dokumentálását is adja a "szellemgyenge” császár „sajnálatra méltó személyiségének" (valamint saját humor iránti érzékenységnek). ${ }^{41}$ Mindaz külön kutatás tárgyát képezné, hogy Petrichevich Horváth János bécsi pályafutása során milyen egykorú karikatúra-ábrázolásokkal találkozhatott, miután a császárváros a különböző európai irányzatok vérkeringésének alapvető része volt, mindenesetre a feltételezhető külföldi hatásokat és divatos formanyelvet saját témáira, saját életének szereplőire formálta, vagyis önálló erejű karakterábrázolással rendelkezett. A rendkívül gyér forrásanyagból, ami Petrichevich Horváth János működésével kapcso-

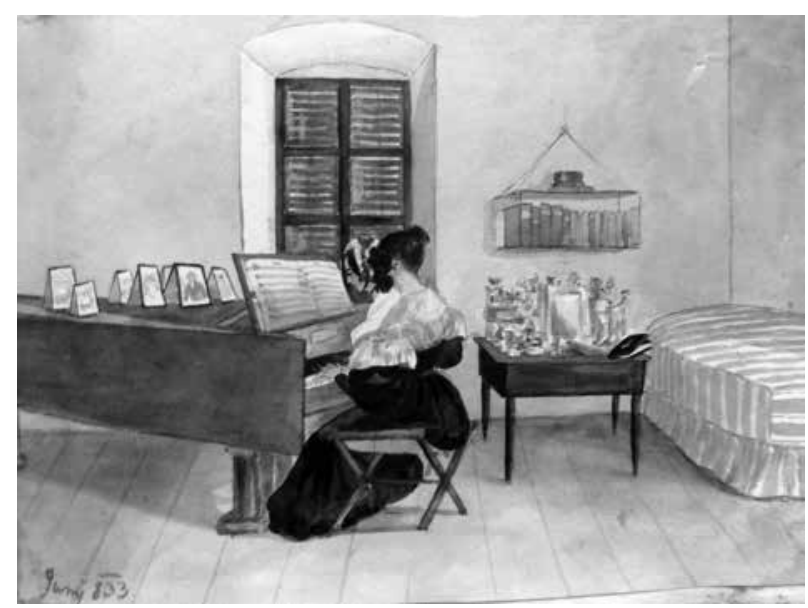

13. Petrichevich Horváth János: Két hölgy a zongoránál, 1833

latban rendelkezésre áll, egy rövid utalás található arról, hogy valószínűleg tudatosan kereste és tanulmányozta az elé kerülő karikatúrákat. Említett viszszaemlékezései közt (mely főként a márciusi bécsi forradalom katonai lépéseiről számol be) található az alábbi megjegyzés, amely arról tanúskodik, hogy a stratégiai és fegyverkezési ügyek mellett másra is kiterjedt figyelme: „Több legmagasabb és közép állású férfinak gyalázatos és nyers torzképei között jelesen egyet láttam, mely sem nyers, sem hamis, $\mathrm{s}$ még élctelen sem volt. Ugyanis ugyanazon főt háromszor lehetett egymás mellett lerajzolva látni. Az elsőnél egy vastagon és magasan kötött nyakkendő egészen az állig nyúlt fel, azon modorban, amint a főherceg Lajos szokta azt viselni. Alatta ezt lehetett olvasni: Március 13ka 1848. A másodiknál a nyakkendő az orráig ért fel. Alatta volt írva: »Március 14ke 1848. "Végre a harmadik a nyakkendőbe volt süllyedve egészen a homlokáig, alatta volt: »Március 15ke 1848. «" 42

Petrichevich rajzai a kontextuális és műfajtörténeti megközelítés mellett az irodalomtörténettel szomszédos ikonográfia szempontrendszere felől is vizsgálhatók, amely nem az alkotások vizuális formaproblémáira kíváncsi, hanem arra, hogy azok milyen társadalmi-történeti determináltsággal rendelkeznek. Tárgykörébe így nem csupán a végleges megfogalmazások, hanem a vázlatok vagy „realisztikus" képek is beletartozhatnak. ${ }^{43}$ Panosfky (az ikonológia kategóriájától elkülönítő) meghatározása szerint „az ikonográfia a múvészettörténetnek az az ága, amely a műalkotások tárgyával vagy jelentésével foglalkozik, szemben a formájukkal". ${ }^{4}$ Ez a Petrichevich-rajzok értelmezésének egyik érvényes megközelítése lehet: „,a müleírás is szükségszerüen tartalmazza az értelmezés mozzanatát", ${ }^{45}$ amely ma már ismeretlen jelentéstartalmakat hozhat felszínre. 


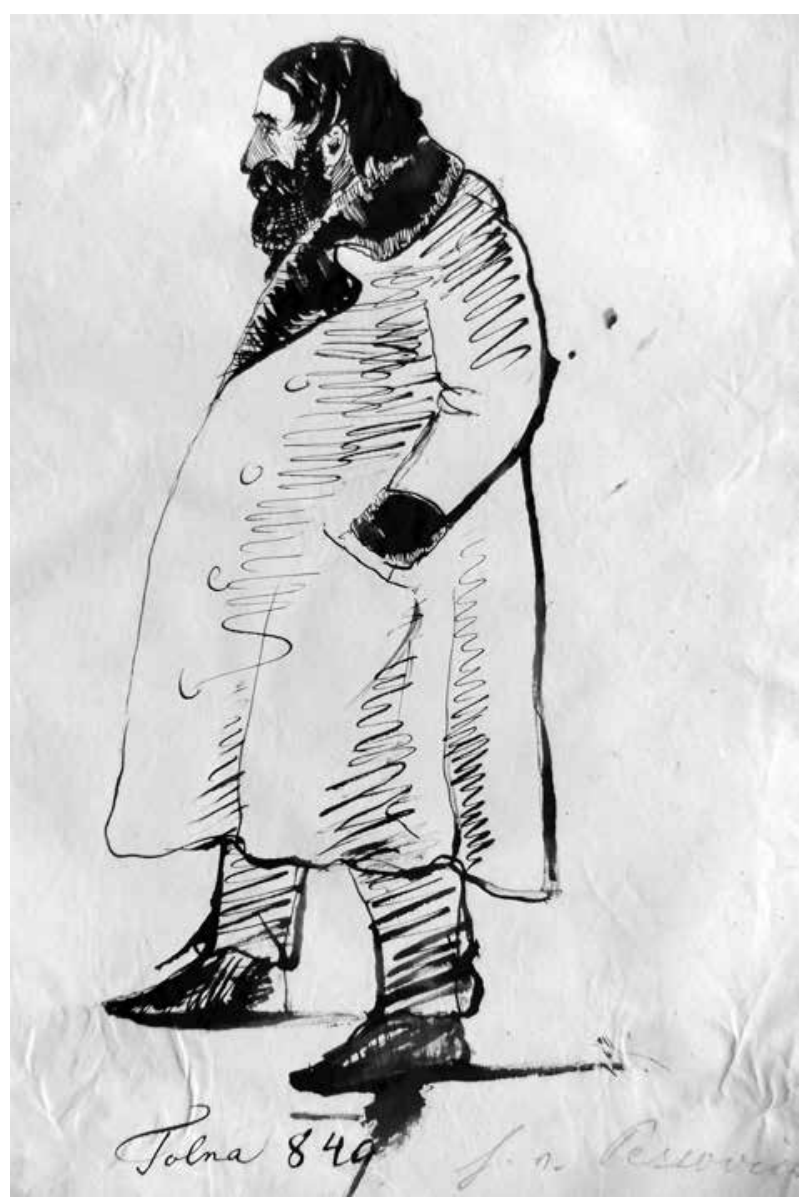

14. Petrichevich Horváth János: Pecsovics Ferenc, Tolna 1849

Petrichevich kötetlenebb múvészi figyelmét (tiszti-nemesi pozíciójával szemben) társadalmi előítéletek kevésbé befolyásolhatták, albumaiban ugyanis minden társadalmi osztály (a legszegényebb kéregetőtől Ferenc Józsefig) ecsetjének végére kerül. Múvei jelentőségét emeli, hogy a reprezentatív körök mellett azokat is érdemesnek találta megörökíteni, akikről ez időben nem volt szokás ábrázolást készíteni. Ábrázoltjai közt a társadalom peremén élő alakok is találhatók: például csavargó, bolond, idős sekrestyés, öreg kertészasszony, szolgák, vagy olyan köznapi foglalkozású emberek, mint a szakács, a kovács vagy a postás - mindezek pedig a kor szélesebb körű olvasatához segíthetnek hozzá. Zsánerképei számos tabutémát feszegetnek. A katonaéletnek nem csupán illusztris oldalát szerepelteti, több ízben megjeleníti például a szükségüket végző tiszteket, kótyagos katonákat. Mappáinak egyik domináns tematikája kétségtelenül a hadi világ, amely gazdag háttéranyagot szolgáltat. Számos uniformis jelenik meg a rajzokon, ahogyan a tábori élet mindennapjai, kártyázó, pipázó, muzsikáló, szundikáló bakák is megelevenednek. Az

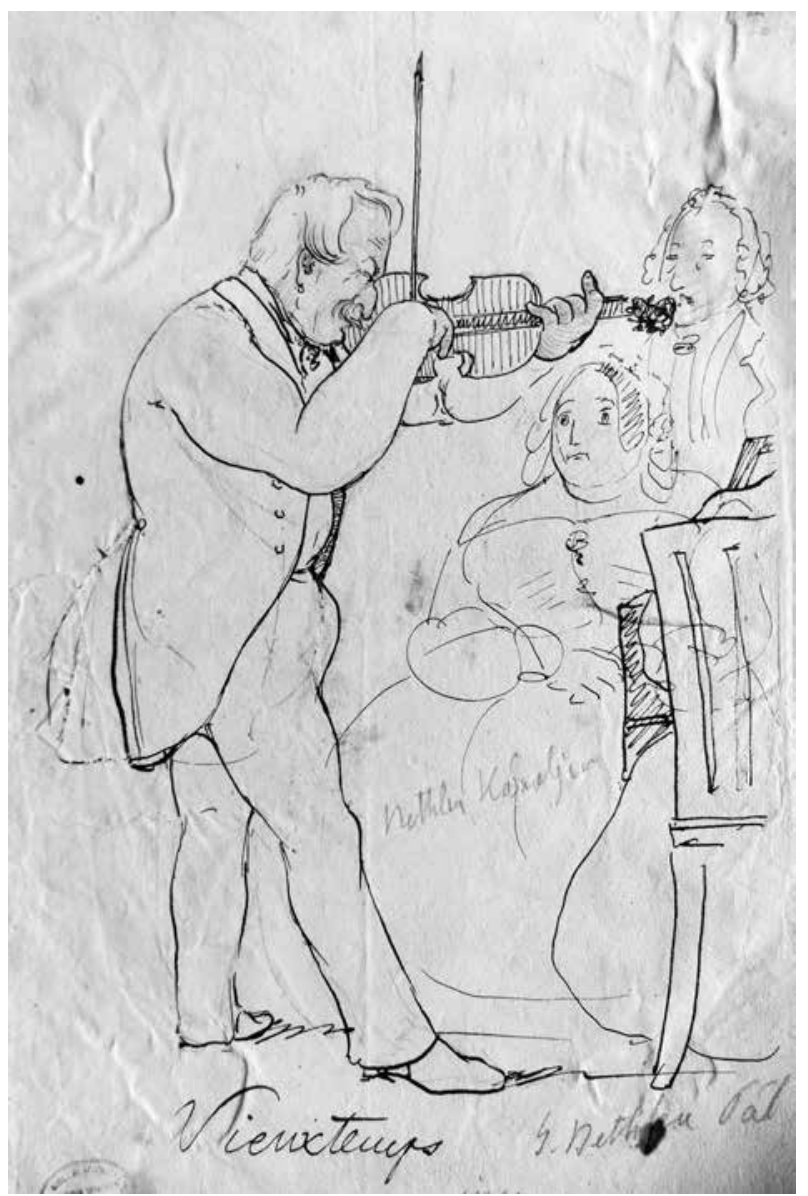

15. Petrichevich Horváth János:

Henri Vieuxtemps hegedüvirtuóz, é. n.

albumok a szabadságharc idejéről is tartalmaznak katonaképeket, csatajeleneteket.

Petrichevich másik lényeges tárgyköre az erdélyi nemesség - a politika és a szalonélet -, illetve albumaiban fel-felbukkannak a bécsi császári udvar egyes szereplői is. Karikatúrái nem kímélik saját társadalmi osztályának tagjait vagy akár a klérust sem, találó, eleven hatású ábrázolásai általános emberi gyengeségeket, testi-lelki torzulásokat húsbavágóan ragadnak meg. Rajzai épp ezért hatnak humorosan most is, kitágítva a múfaj általános attribútumát, miszerint a „mának szól”, s épp ezért csak jelen időben értelmezhető. Mappái közt számos karikatúrán ábrázolja önmagát, iróniája tehát saját személyére is kiterjed. Önreflexivitásának további jele, hogy több képen rajzolás közben jelenítette meg magát.

Képeinek kisebb - de nem elhanyagolható - hányadát képzik a miliőrajzok, illetve tájképek. Az egyes enteriőröket megjelenítő kompozíciók a biedermeier tárgyi kultúráját, valamint tevékenységi köreit mutatják, hasznos adatokat szolgáltatva korabeli szobabelsők, öltözékek stb. szempontjából, 


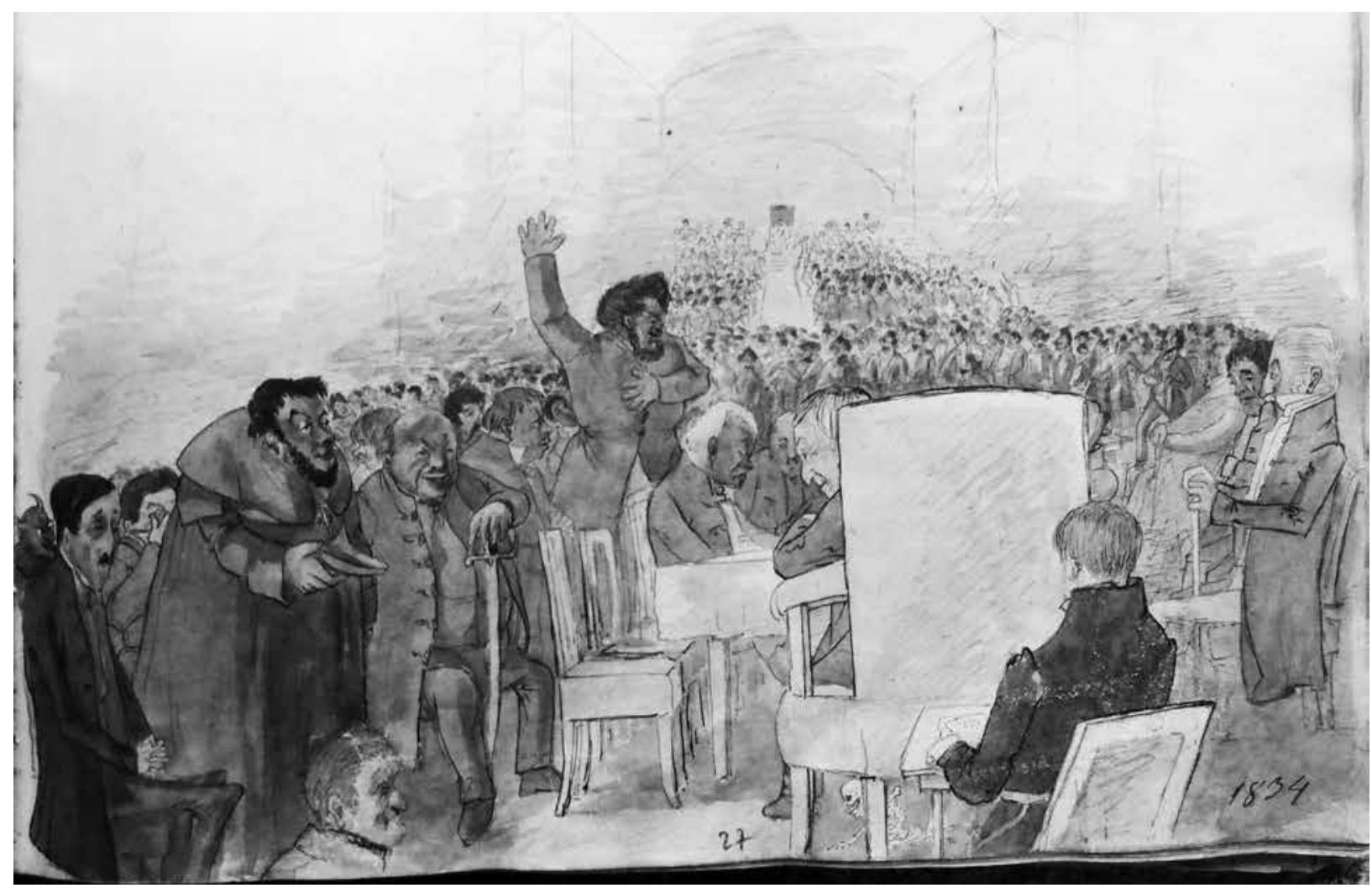

16. Petrichevich Horváth János: A nagykárolyi megyegyúlés, 1834

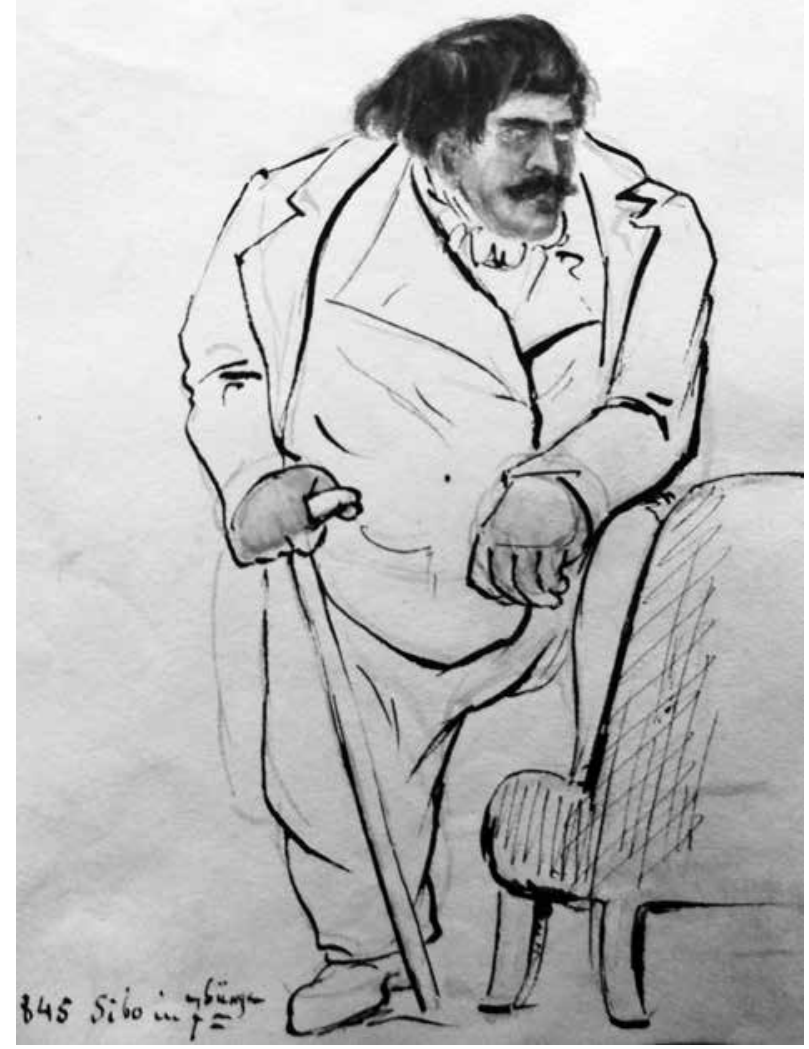

17. Petrichevich Horváth János: Wesselényi Miklós Zsibón, 1845 miközben bevezetnek a magas rangúak hétköznapi világába. A különböző báli vagy szalonábrázolások közt például olyan müvelődéstörténeti szempontból (is) érdekes jelenetek bukkannak fel, mint például a főúri társaság 1837-es szebeni Norma-előadása, vagy egyéb farsangi szokások, szabadidős elfoglaltságok.

A politikatörténeti, müvelődéstörténeti vagy történelmi kánon több meghatározó személyisége szerepel az albumokban. Erdemes tehát a számos név közül néhány jelentősebbet (a teljesség igénye nélkül) kiemelni, amelyekkel reprezentálni lehet a repertóriumszerüen itt most nem bemutatható anyagot. Ilyen Mikó Imre („Erdély Széchenyije”), Esterházy Pál, az első felelős kormánynak a király személye körüli minisztere, Jósika János guberniumi elnök, akit Kazinczy Ferenc is meglátogatott erdélyi utazása során, és akinek epigrammát is ajánlott. ${ }^{46} \mathrm{Az}$ utazó és tájépítész Hermann von Pückler-Muskau is feltünik a lapokon. Továbbá Felix Jablonowski herceg, császári katonatiszt, aki a Téli hadjárat során játszott jelentős szerepet; Franz von Lichtenstein herceg, aki Windisch-Grätz hadseregében a schwechati csatától kezdve részt vett a szabadságharc hadi eseményeiben; Felix von Schwarzenberg herceg, aki 1848 után a császárság miniszterelnöke és külügyminisztere lett. Megemlítendő Czecz Antal botanikus, Pergő Celesztin, a magyar színészet hős- 


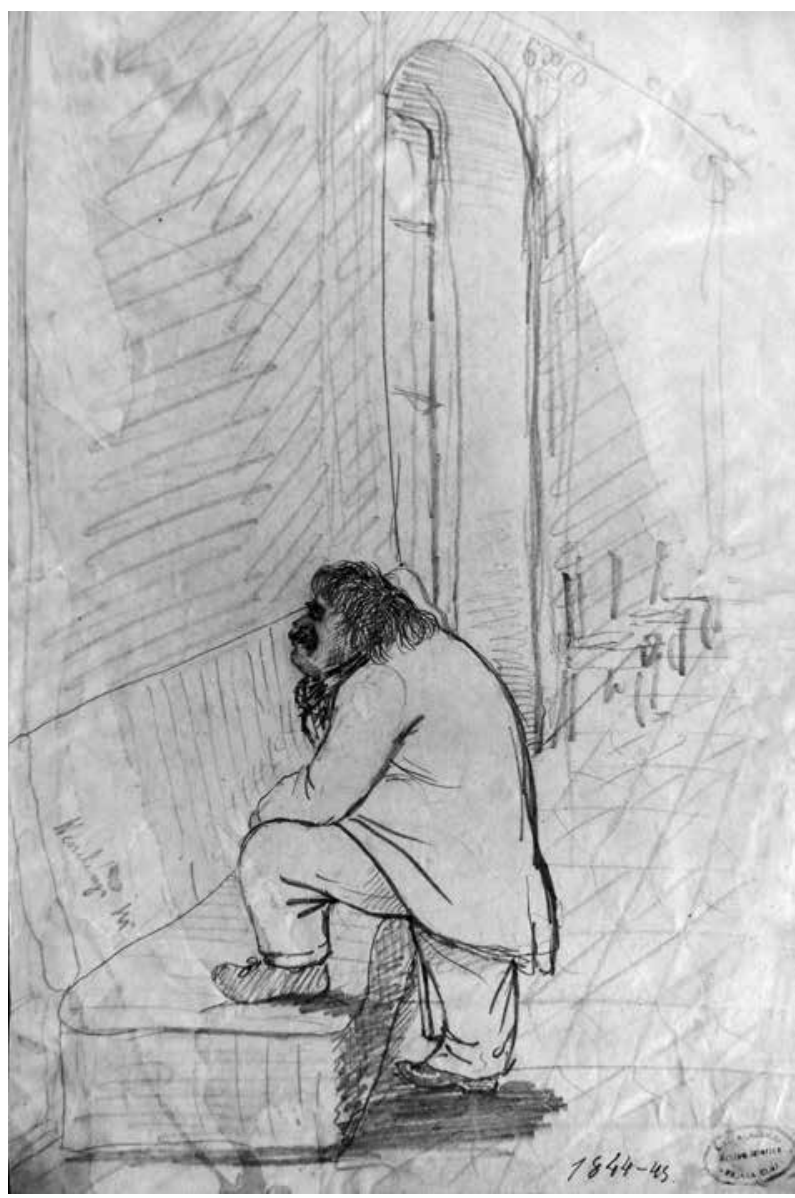

18. Petrichevich Horváth János:

Wesselényi Mikós a börtönben, 1844-1845.

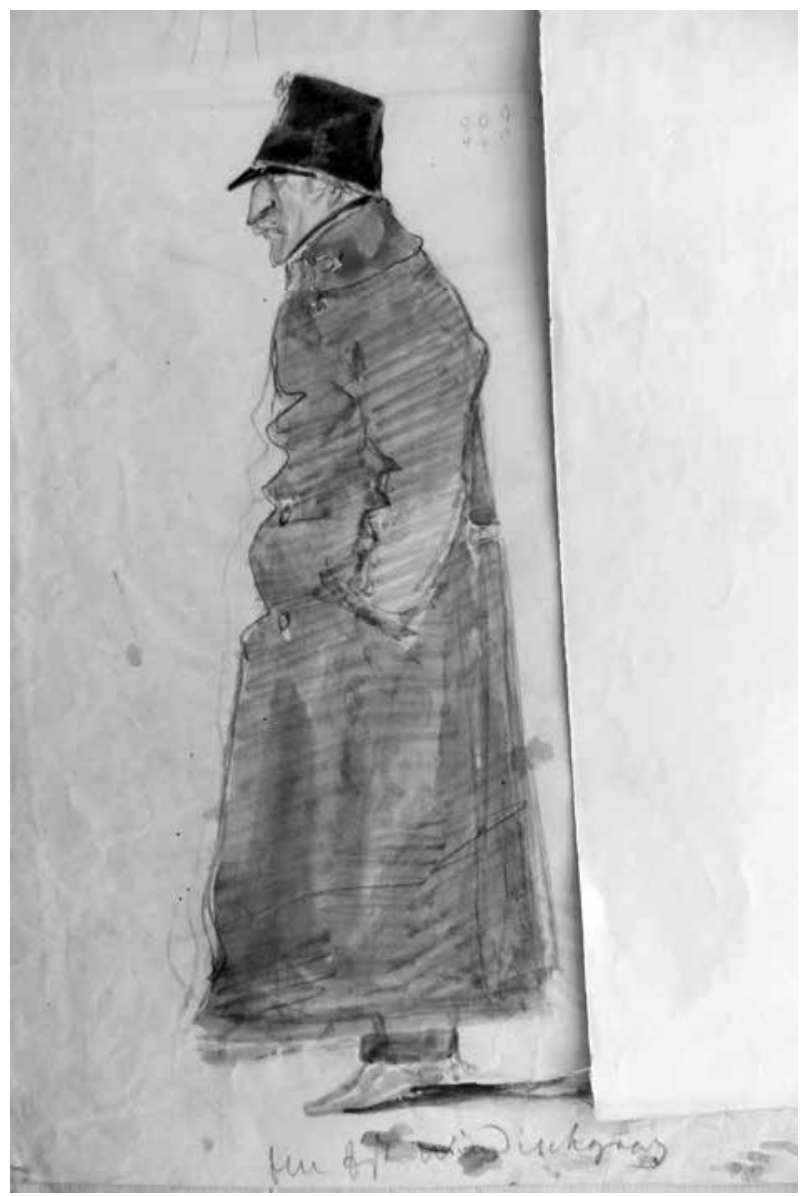

19. Petrichevich Horváth János:

Alfred Candidus Ferdinand zu Windisch-Grätz herceg, é. n.

közzé; a szintén ellenzéki szellemű Kemény Sámuel, az Erdélyi Múzeum gyưjteményének egyik jelentôs adományozója; Kemény Dénes, az erdélyi reformkori ellenzék egyik kulcsfigurája, nagyhatású szónok; Bethlen Domokos királyi kamarás, az első magyar nyelvű elméleti közgazdasági mű szerzője; Zeyk Dániel főkormányszéki tanácsos, számos felvilágosult cikk írója; Rhédey Ádám, az erdélyi református oktatás mecénása; Rhédey László, Rhédey Klaudia édesapja, akinek dédunokája VI. György, angol király lett; Cserei Miklós, erdélyi kormányszéki tanácsos, tudománypártoló, színházbarát, Kazinczy levelezőpartnere. Végül a már említett Teleki László, Széchenyi Ferenc vagy Wesselényi Miklós, akit amellett, hogy udvarlás közben és börtönben is megörökített a rajzoló, az 1834-es nagykárolyi megyegyưlésen tartott vad szónoklata közben is ábrázolt. Akiket pedig nem kell különösebben bemutatni: Metternich, Radetzky, Windisch-Grätz, V. Ferdinánd, Ferenc József ugyancsak szerepelnek az alkotások között. Számos további kép ikonográfiai azonosításra vár, vagy ha névvel jelölve is van az ábrázolt, az illető kortörténeti helyének meghatáro- 
zása a vonatkozó diszciplínák (történettudomány, politika-, hadtörténet stb.) feladata lesz.

Ami a mappák további recepcióját illeti, az albumok „nem reprezentatív” portréi sajátosan egészíthetik ki például a Barabás-életmű történeti jelentőségét, amelyet a késői kortárs, Reviczky Gyula (1855-1889) fogalmazott meg ekképp: „megfestéd korod arcképcsarnokát" ${ }^{47}$ Barabás korai erdélyi portréi és Petrichevich albumainak szereplői közt ugyanis jelentős az átfedés.

Elvégzendő feladat továbbá az albumok itt most egyáltalán nem érintett müvészettörténeti megítélése, amely például a magyar rajzmüvészet és vízfestés történetébe illesztheti a kidolgozottabb alkotásokat, vagy egybevetheti őket például az igazán nagy jelentőségü Barabás-akvarellekkel. Petrichevich albumai új viszonyítási pontot teremthetnek a Barabás-recepcióban, hiszen számos tematikus egyezés fedezhető fel a nagy festő munkáival. Barabásnak a gräfenbergi fürdőélet alatt készült szatirikus, profán, intim, könnyed vonalvezetésü képei - amelyek az életmúvön belül különös szere- pet töltenek be $-{ }^{48}$ mind tematikájukban, mind formaproblémáikban érdekes párhuzamot mutatnak Petrichevich rajzaival. Izgalmas együttállásról tanúskodnak Barabás erdélyi tájképek sorozatának egyes darabjai és Petrichevich egy-egy tájképe - ezek egybevetése is új kutatási eredményekhez vezethet. ${ }^{49}$ Petrichevich mappái közvetve ismételten ráirányíthatják a figyelmet a 19. század hazai akvarellfestészetére, amely a kanonizált műfajok sorában sokáig kevésbé fontos szerepet töltött be.

Végül ismét hangsúlyozni szeretném, hogy Petrichevich mappái a 19. század első fele, középső harmada történetének jelentős vizuális forrásanyagát tartalmazzák. A rajzokat számításba kell vennünk, ha a magyar politikai és kulturális karikatúra kezdeteit akarjuk felderíteni. A lapok művészi megfogalmazásmódja, zavarba ejtő őszintesége eddig nem ismert perspektívából láttat(hat)ja e periódust, így akár az aranykor fátylával beburkolt reformkornak vagy az ördögien megfestett császári haderőknek a megszokottól eltérő képét is elénk vetítheti.

\section{JEGYZETEK}

1 Kolozsvár, Biblioteca Academiei Române ClujNapoca, MS. A1, vol. I-IV. Az albumok anyagának összerendezése, a képaláírások, datálások vizsgálata számos további kérdést vet fel, mely további kutatásokat igényel, és egy következő tanulmány tárgya lehet. Az MS A1/IIII. Petrichevich-korabeli mappák, melyeknek saját lapjain szerepelnek a képek, az MS A1/IV. azonban egy időben későbbi fotóalbum lapjaira ragasztott képeket tartalmaz. A negyedik, egyébként legkevesebb müvet tartalmazó mappa történetét homályossá teszi, hogy az albumok első ismertetője, Bíró Béla az 1940-es években még csak három albumról számolt be. Bár a művek azonos kézjegye, motivikus és tematikus egyezései határozottan összekötik a négy gyưjteményt, a szerzőséggel kapcsolatban további vizsgálódásokra lehet szükség. A rajzok egy jó részét saját képaláírással és dátumozással látta el a szerző, azonban egy későbbi szerkesztő szignatúrája is feltünik a lapok közt, aki ceruzával kommentálta (főként nevekkel látta el) az alkotásokat.

2 Bíró Béla: Erdélyi biedermeier müvészet. Erdélyi Helikon 1944/8, 439. Köszönöm Petrichevich Horváth János leszármazottjának, Horváth Tholdy Péternek, hogy felhívta a forrásra a figyelmem.

3 Uo. 445.

4 Rózsa György - Spira György: Negyvennyolc a kortársak szemével. Képek, nyomtatványok és iratok. Budapest 1973. - A szerzők az albumokhoz Vayer Lajos ikonográfiai összeállítása nyomán jutottak el, Vayer ugyanis Széchenyi ábrázolásainak összegyújtésekor beszámolt egy „Ismeretlen mestertől” származó kőnyomatról, amelynek másolata a Székesfővárosi Könyvtár állományában volt található. Vö. Vayer Lajos: Széchenyi képe. Magyarságtudomány I. 1942/1, 100, 109. Rózsa György ezen a nyomon továbbhaladva bukkanhatott rá az Erdélyi Múzeum kolozsvári gyüjteményében az eredeti rajzra, ezáltal pedig Petrichevich Horváth János mappáira.

5 „A Gróf Toldi Családnak utolsó ivadéka Toldi Samuel 80 egynehány éves öreg fimaradék nélkül - Gróf Toldi nevet nyert azonban tábornok báró Petrityevity [sic!] Horváth János és így a név fen fog maradni, míg ennek maradéka lesz - és a vér is némi tekintetben mert Horváthnak nagyan[n]ya Gr. Toldi leány volt. - Petrityewith Horváth János tábornok elébb báróságot nyert, azután Gr. Toldi név mellékletet" Vö. Gr. Gyulay Lajos maga keze és könyve - Döbrentei Gábor és Gyulay Lajos naplófeljegyzései, 167. oldal (gyulaynaplok.hu/showDetailedDokumentum. php?dokID=13567 - utolsó letöltés ideje: 2015. június 15.)

6 Rózsa-Spira i. m. (4. j.) 105.

7 Spira György: A nemes gróf vízbe pottyanása. História VII. 1985/2., 10.

8 Uo.

9 Széchenyi világai. Szerk. Tóth Csaba. Budapest 2010, valamint Cs. Lengyel Beatrix - Gödölle Mátyás: Teleki László ismeretlen arcai. Rubicon 2011/12., http://www. rubicon.hu/magyar/oldalak/teleki_laszlo_ismeretlen_arcai, utolsó letöltés: 2015. május 30. Petrichevich Teleki-ábrázolásaira korábban Cennerné Wilhelmb Gizella is felhívta a figyelmet: Cennerné Wilhelmb Gizella: Teleki László arcképei. Folia Historica. A Magyar Nemzeti Múzeum Évkönyve XIV. 1989, 30.

10 Cs. Lengyel-Gödölle i. m. (9. j.)

11 A Petrichevich Horváth családról és egyes tagjairól rendkívül csekély dokumentum áll rendelkezésre. A tanulmány tartalmazza mindazt az információt, amely Petrichevich Horváth Jánosról pillanatnyilag elérhető. A Petrichevichek több évszázados, küküllőszéplaki bir- 
tokán őrzött levéltár és könyvtár az első világháborúnak esett áldozatul (vö. Arhivele Statului din Cluj Napoca, Fond Kelemen Lajos 69-71), az itt megmentett néhány dokumentum, amely a második világháború alatt az Erdélyi Múzeum-Egyesület (EME) gyüjteményében megmenekülhetett, jelenleg lappang. Az EME Levéltár anyagát ugyanis „1974-ben átvette az Állami Levéltár kolozsvári fiókja, majd elszállították Kolozsvárról, és a »szekuritáté« rendelkezett vele". L. Egyed Ákos: Előszó. In: Az Erdélyi Múzeum-Egyesület gyüjteményei. Kolozsvár 2009, 10. A Petrichevich Horváth-hagyaték - vagy legalábbis egy része - ugyan a városban maradt, hiszen a helyi Állami Levéltár átvételi elismervényében szerepel e címkéjü anyag, azonban a gyaníthatóan nem túl terjedelmes fondot „,beolvaszthatták” valamely másik irathalmazba, így nem hozzáférhető. (Flóra Ágnes szóbeli közlése, Arhivelor Naționale din Cluj Napoca.)

12 A 16. század első felében a törökök horvát területeken végzett pusztításai elől menekülve radochi Petrichevich Miklós lépett először Erdélybe (a migráció pontos idejét tekintve ellentmondanak a források), később felvette a Horváth nevet. „E család szerencsés házasságok által magát csakhamar igen kedvező helyzetbe hozta." Már az erdélyi családalapító, Miklós is komoly közéleti szerepet vállalt: „alkalmasint Izabella királynét kíséré” Erdélybe 1541-ben, majd pedig a „kolozsvári országgyưlés 1555. nov. 28-án János-Zsigmond behozatala ügyében őt küldi követül Ferdinánd császárhoz". Fia, I. Kozma Erdély első fejedelme „alatt Vécsvár [Marosvécs] gondviselője, a Báthoriak alatt (1578-90) a fogarasi vár kapitánya és fejedelmi tanácsos". 1584-ben telepednek meg Küküllőszéplakon [románul: Suplac, németül: Schöndorf, Románia, Maros megye], s innen „a kis Küküllő mellett fekvő Széplakról vették előnevüket". A család sokáig közeli, sőt bizalmi kapcsolatban állt az (akár egymással ellenséges) erdélyi fejedelmekkel, így Petrichevich Horváth János (a rajzoló szépapjának, II. Kozmának testvére) Kemény János udvarában, egy másik testvérük, III. Miklós Apafi Mihály udvarában szolgált bejáróként, míg harmadik testvérük, II. Ferenc Apafi Mihály pohárnoka. Petrichevich szépapja, Kozma ugyancsak jelentős katonai, valamint jogi-tisztviselői pályát futott be II. Rákóczi György „zivataros” uralkodása alatt. Vö. Kővári László: Erdély nevezetesebb családai. Kolozsvár 1854, 120; Sándor Imre: A széplaki PetrichevichHorváth család. Különlenyomat a Genealogiai Füzetek 1908. évfolyamából. Kolozsvár 1908, 3, 8-19.

13 Amellett, hogy a család több unitárius templom építtetője (pl. a kolozsvári, a küküllőszéplaki), kegytárgyak ajándékozója, iskolák fenntartója, öt főgondnokot (a legmagasabb unitárius világi tisztség) is adtak egyházuknak. Vö. Sas Péter: Kelemen Lajos kiadatlan összeírásaiból. Müvelődés LXIV. 2011. október, o. $\mathrm{n}$.

14 A magyar színikritika kezdetei 1790-1837. S. a. r. Kerényi Ferenc. Budapest 2000, 1507; a fordításokról 1. uo. $136,425,677,733$.

15 János testvére, Lázár Párizsból írja húguknak egy 1845-ös levelében: „[H]at héti keresésem után feltaláltam kedves régi francia tanítónkat, Ménard urat. Képzelheted a viszontlátás örömét húsz esztendei távullét után. Ố kedves Erdélyünket máig is siratja, pedig boldog családfő, nemzeti őrségi tiszt, kardalnok a nagy operaház- ban, kalmárka és divatos zongorahangoló!" Petrichevich Horváth Lázár: Új levelek Emiliához. Honderü III. 1845/I/17. szám, 170. [kiemelések tőlem, KAE]

16 Öccse, Lázár írja egy levelében szintén húguknak: „emlékezzél csak vissza olykori színi működéseinkre” Petrichevich Horváth Lázár: Kaleidoskop. In: Petrichevich Horváth Lázár Munkai IV. Buda-Pest 1842, 48.

17 János öccse, Lázár így vall erről naplójában: „atyám literátor, és verseket irt a maga idejében. (A torma csípőssége ellen p[éldának] o[káért], mert [...] Torma Éva, ki nevelte unokáját g. Lázár Evvát, az anyámat, nem akarta hozzáadni apámhoz, ki szarvasbőr nadrágban, kappancs lábbal, vereses mellényt francia frakkal és széles karikával fülében érkezett volt haza a külföldről, s kit ország bolondjának hívogatott szülő anyám) fordította az ős anyát, Zrínyit, s több más drámákat. Dani testvérem Poëtaster és literátor, Emília testvérem nagy belletrista s János ki az Ingenieur Academia nevendékje - hol katonaságra készült - ő sem tagadhatja meg költői szellemét. Sőt az anyám is nagy litteratix, fordította Tarenti Juliust, a Hajadonokat s a t." Petrichevich Horváth Emil: A Petrichevich család naplói. Budapest 1941, 3.

18 Petrichevich Horváth Lázár írja egy levelében Széchenyi Istvánnak: „Honos örömmel értettük Méltóságod pártfogó kegyét, mellyel egy igen derék hazánkfiát a sokatigérő fiatal Barabást szerencséltetni szíveskedett. - Azt számára továbbra is kikérni bátorkodok, mint ki individualis becséről is kezeskedhetek. Házunknak régi ösmerője lévén." 1836-ban Kolozsváron kelt levélből, [kiemelés az eredetiben!], Budapest, Magyar Tudományos Akadémia, Könyvtár és Információs Központ, Kézirattár, K 207/166

19 Barabás Miklós Önéletrajza. Kolozsvár 1944, 238, 243.

20 Lapjában, a Honderüben értő cikkeket közöl a pesti és a bécsi képzőművészeti kiállításokról, a lap több genre-képét, metszetét, litográfiáját is Barabás Miklóssal készítteti, továbbá 1844-től a Pesti Müegylet Műbíráló, majd Igazgató Választmányának tagja. Vö. Szvoboda Dománszky Gabriella: A Pesti Müegylet története. Miskolc 2007, 274-277.

21 Petrichevich Horváth Emil i. m. (17. j.) XXIV-XXIX.

22 Érdekes, hogy az adott társadalmi tér mennyire meghatározó lehet az identitás konstruálásában. Míg Petrichevich Horváth János a forradalom leverése ügyében harcol, addig Erdélybe költözött német sógora a magyar szabadságharc oldalán küzdött az erdélyi hadszíntéren: „Rindsmaul Albert gróf [...] mint katonatiszt Erdélybe szakadt, azáltal, hogy 1836. dec. 6-án elvette a kolozsvári színház egyik építtetője és a megnyitásnál Zrínyit játszó Petrichevich Horváth Dániel és gr. Lázár Éva leányát, Emíliát, az akkori irodalomban szerepet játszó P. Horváth Laczi [Lázár] nővérét. Az akkori főúri társaság egyik legneveltebb s legszellemesebb kedvencét. [...] Albert gróf középtermetű szőke férfi. A nász után a nyárádmenti Jobbágyfalván, neje birtokán vettek lakást. Maga a gróf rajzol, fest, a német lapokba az erdélyi viszonyokról szóló közleményeket ír. Jó magyar ember lett. A forradalom alatt honvédőrnagy, mint ilyen védi Csíkban a Gyimesi-szorost 12 ágyúval, midőn vette aug. 1-én a hírt, hogy Gál Sándor feladta a Székelyföldet. A gróf oda szorult, kivágta magát, ágyúit elásta." Kővaáry László: A millennium századában Erdélyben kihalt főúri csalá- 
dok s visszaemlékezés végső sarjai szereplésére. Erdélyi Múzeum XVIII. 1901. június 18., 329.

23 Petrichevich-Horváth János Emlékirata 1848-49-ről. In: Petrichevich Horváth Emil i. m. (17. j.) - A kézirat lelőhelye: Biblioteca Centrală Universitară Lucian Blaga din Cluj-Napoca, Ms 1026.

24 Takáts József: Modern magyar politikai eszmetörténet. Osiris Kiadó, Budapest, 2007, 52. 136.

25 Petrichevich-Horváth János Emlékirata i. m. (23. j.)

26 Uo. 136-137. Jól ismert Széchenyi naplójának egyik utolsó bejegyzése: „Meghalt Jósika! Pótolhatatlan veszteség!" Széchenyi István: Napló. Budapest 1987, 1355.

27 Greguss Ágost: A torzképről. A Kisfaludy Társaság Évlapjai IV. Athenaeum, Pest 1869, 121.

28 Uo. 127

29 A források említett hiánya következtében csak spekulatív megállapításokat lehet tenni arra vonatkozóan, hogy mi ambicionálhatta Petrichevichet karikatúrák készítésére. Miután már 1820 előtt is Bécsben nevelkedett, első karikatúrái pedig 1824-re datálhatók, talán a császárvárosban találhatott rá erre a népszerü, alkatához is illő műfajra, melyet elsősorban valószínűleg saját szórakoztatására, valamint szalonsikerek érdekében készíthetett. (Petrichevich Horváth Emil tanúsága szerint leveleit például, melyeket időnként illusztrált, ,"kézről-kézre adogatták a kolozsvári úri kaszinóban, s hetekig mulattak tartalmukon". Petrichevich Horváth Emil i. m. [17. j.] XXVII.) Származásának és hivatásának köszönhetően anyagi célokra nem kellett felhasználnia rajzkészségét, így vélelmezett motivációi közt hangsúlyossá válik az önismeretilétértelmező aspektus, valamint egyfajta „,terápiás" mozzanat is (ti. rajzolás szemben a katonai rigorozitással). Rajzmappái széles politikai és társadalmi tablót festenek, így ambíciói közt lehetett a kordokumentáció is, erre irányuló hajlamát bizonyíthatja Emlékirata az 1848-as bécsi márciusi eseményekről.

30 Nagyné Nemes Gyöngyi - Andor Csaba: Madách Imre rajzai és festményei. Képek egy életmű hátteréről. Madách Irodalmi Társaság, Budapest 1997, 9, 13.

31 Szíj Béla: Jókai Mór képzőmüvészeti érdeklődése. Veszprém Megyei Múzeumok Közleményei 18. 1986, 503-516.

32 Vayer i. m. (4. j.) 94. - Széchenyi Franciska egyszerü képei, melyek érdekes dokumentumként hatnak például a nagycenki Széchenyi-kastély kiállításain, művészi értéket nemigen képviselnek.

33 Madách Imre rajzai és festményei i. m. (30. j.) 37.

34 Barabás Miklós (1810-1898) akvarelljei. Az előszót írta és a katalógust összeállította Szvoboda D. Gabriella. (A magyar rajzmüvészet mesterei, 1.) Magyar Nemzeti Galéria, Budapest 1985, oldalszám nélkül.
35 H. Szilasi Ágota: A modern magyar akvarellfestészet elindítója. In: Jánó Mihály szerk.: Barabás Miklós. Előadások a múvész halálának 100. évfordulójára szervezett konferencián. Sepsiszentgyörgy 2001, 51.

36 További műfaji áttekintések magyarul: Buzinkay Géza: Borsszem Jankó és társai: Magyar élclapok és karikatúráik a XIX. század második felében. Budapest 1983; Fabó Edit: A dualizmus kori magyar karikatúrák és paródiák. A nőkkel kapcsolatos társadalmi sztereotípiák változása az élclapok tükrében. Doktori disszertáció. ELTE BTK, Történettudományi Doktori Iskola, Budapest 2007. L. még: Szvoboda Dománszky Gabriella: A magyar biedermeier. (Stílusok - korszakok) Budapest 2011, 128-129.

37 Martin Rowson: Satire, sewers and statesmen: why James Gillray was king of the cartoon. The Guardian, 2015. március 21, www.theguardian.com/artanddesign/2015/ mar/21/satire-sewers-and-statesmen-james-gillray-kingof-cartoon (utolsó letöltés ideje: 2015. július 13.)

38 Uo.

39 Greguss i. m. (27. j.) 125, 129.

40 „A bécsi Hadilevéltárban folytatott kutatás során Petrichevich Horváth János személyével kapcsolatban katonai szolgálati adatokat találtunk, képzőmüvészeti tevékenységével kapcsolatosan sajnos semmiféle adatot nem leltünk." Számvéber Norbert szíves szóbeli közlése

41 Petrichevich-Horváth János Emlékirata 1848-49-ről i. m. (23. j.) 103-105.

42 Uo. 106.

43 Vö. Pál József: Ikonológia mint összehasonlító irodalomtudományi diszciplína. In: Pál József szerk.: Az ikonológia elmélete. (Ikonológia és műértelmezés, I.) Szeged 1986, 3-10; ill. Louis Réau: Az ikonográfia meghatározása és alkalmazása. In: Uo. 267-290.

44 Erwin Panofsky: Ikonográfia és ikonológia: bevezetés a reneszánsz művészet tanulmányozásába. In: Uő: A jelentés a vizuális művészetekben. Budapest 1984, 284.

45 Beke László: Panofsky és az ikonológia. In: Panofsky i. m. (44. j.) 382-399.

46 Kazinczy Ferenc összes költeményei. S. a r. Gergye László. (Régi Magyar Költők Tára, XVIII. század, II.) Budapest 1998, 65 (32. sz.), 257.

47 Reviczky Gyula: Barabás Miklóshoz. In: Reviczky Gyula összes verse. S. a. r. Császtvay Tünde. Budapest $2007,388$.

48 Vö. E. Csorba Csilla: Barabás és Priessnitz. In: Jánó Mihály szerk.: Barabás Miklós. Előadások a művész halálának 100. évfordulójára szervezett konferencián i. m. (35. j.) 69-80.

49 Vö. Barabás Miklós (1810-1898) akvarelljei. i. m. (34. j.), 63-68. sz. 


\section{THE UNKNOWN BEGINNINGS OF THE POLITICAL-CULTURAL CARTOON IN HUNGARY. COLLECTION OF DRAWINGS BY JÁNOS PETRICHEVICH-HORVÁTH}

In the library of the Romanian Academy of Sciences in Kolozsvár there are four albums containing hundreds of caricatures, genre and milieu drawings, political portraits by János Petrichevich Horváth from the period between 1824 and 1864. The albums comprise several so-far little known and unpublished depictions of actors of the age such as István Széchenyi, Miklós Wesselényi, László Teleki, Sándor Teleki, Ferdinand V, Metternich or Emperor Francis Joseph, as well as the less widely known figures of the Transylvanian public scene and nobility, and officers of the imperial army. The set of over five hundred drawings, some only rough sketches, are not only intriguing in terms of iconography but at the same time have intrinsic artistic value as well. The main asset of the albums is the representation of the $19^{\text {th }}$ century small world of ordinary people besides the pictures of representative personages. In addition to unusual themes the artist also challenges some taboos and depicts the abuses of power showing some infamous aspects of the life of the imperial forces, the aristocracy or the clergy.

By occupation, Transylvanian-born János Petrichevich Horváth was a high-ranking officer in the imperial army, and as such he was a committed defender of the feudal social structure and the monarchy, but as an amateur graphic artist he revealed quite a different side of his activities. Although there is no information on his regular artistic training, his works suggest a trained draughtsman mastering refined drawing techniques, with a sense of colour, careful spatial composition and exact anatomical rendering, correct perspective view and sensitive characterization.

The most remarkable works in the albums are the caricatures, which makes scholarship revise the beginnings and history of the genre in Hungary. Though the first half of the $19^{\text {th }}$ century is regarded as a period of rudimentary attempts in Hungarian caricature history, the unfolding of the genre being dated to after the Compromise (1867), the albums of János Petrichevich Horváth render the Hungarian manifestations of the genre commensurable with the European crop of the genre at an earlier date. Of course, Hungarian art struggling with several problems of (self) definition, institutionalization, lack of infrastructure, etc. did not have a James Gillray (1756-1815) regarded as the "father of political caricature" or an Honoré Daumier (1808-1879) yet, but Petrichevich's works do add several hues to the general tone of backwardness. As a conspicuous analogy, most caricatures of Gillray mock George III whose mental illness was caused by porphyria, Daumier's most famous caricatures are of the pear-headed Louis Philippe I, and Petrichevich's several caricature sketches depict the hydrocephalic Ferdinand V. Thus his works can be taken as the start of Hungarian political and cultural caricature whose artistic rendering and embarrassing sincerity project to us a different picture of the Reform Age clad so far in the veil of the golden age or of the customary image of the imperial forces as devilish impostors.

KASZAP-ASZTALOS Emese, irodalomtörténész, Budapest, Petőfi Irodalmi Múzeum / literary historian, Petőfi Literary Museum Budapest asztalos.emese@pim.hu

Kulcsszavak: politikai karikatúra, Petrichevich Horváth János, Széchenyi István, Wesselényi Miklós, James Gillray, Honoré Daumier / Keywords: political cartoon, Petrichevich Horváth János, Széchenyi István, Wesselényi Miklós, James Gillray, Honoré Daumier 